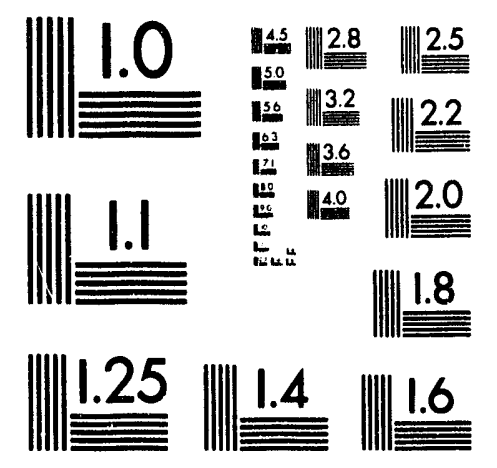



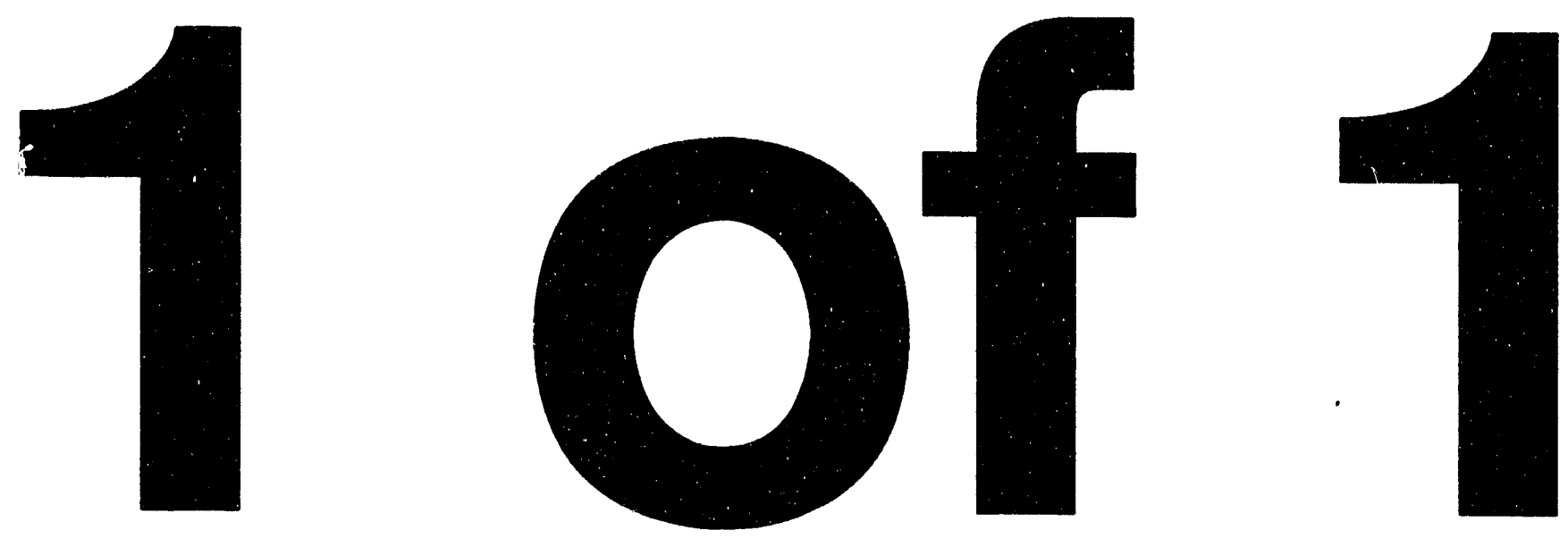


\section{Final Report of the Systems Engineering Technical Advisory Board for the Tank Waste Remediation Program}

Systems Engineering

Technical Advisory Board

F. P. Baranowski

C. B. Goodlett

S. J. Beard

J. P. Duckworth

A. Schneider

L. L. Zahn

Date Published

March 1993

Date Manuscript Completed

February 27, 1993

Prepared for the U.S. Department of Energy Office of Environmental Restoration and Waste Management

(2) Westinghouse Hantord Company Richland, Washington 99352

Hanford Operations and Engineering Contractor tor the

U.S. Department of Energy under Contract DE-AC06-87RL10930

Approved for Public Release

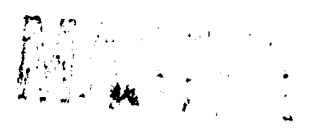




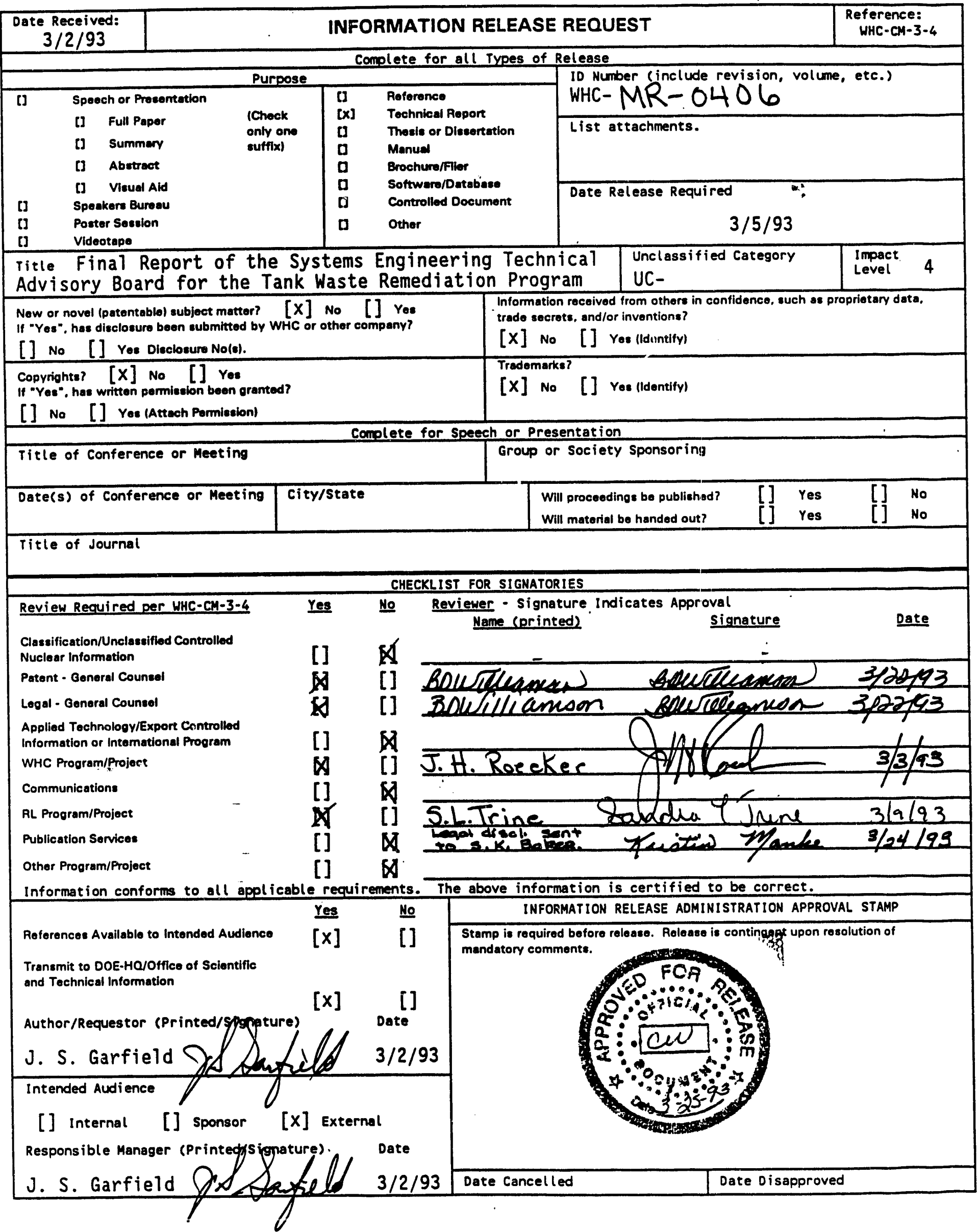




\section{FINAL REPORT \\ OF THE \\ SYSTEMS ENGINEERING TECHNICAL \\ ADVISORY BOARD \\ FOR THE \\ TANK WASTE REMEDIATION PROGRAM}

February 27, 1993

Conducted for the Westinghouse Hanford Company

Richland, WA 


\title{
FINAL REPORT OF THE SYSTEMS ENGINEERING TECHNICAL ADVISORY BOARD FOR THE
} TANK WASTE REMEDIATION PROGRAM

\author{
F. P. Baranowski, Co-Chairman \\ C. B. Goodlett, Co-Chairman \\ S. J. Beard \\ J. P Duckworth \\ A. Schneider \\ L. L. Zahn
}

February 27, 1993

Conducted for the Westinghouse Hanford Company

Richland, WA 


\section{i. TABLE OF CONTENTS}

i. Table of Contents

Page

2

I. Executive Summary

3

II. Background

III. Review

IV. Conclusions

\section{APPENDICES}

A. Board Membership 13

$\begin{array}{ll}\text { B. Status Reports } & 17\end{array}$

1. October $27-29,1992 \quad 18$

2. December $7-9,1992 \quad 24$

3. January $18-21,1993 \quad 33$ 


\section{EXECUTIVE SUMMARY}

The Tank Waste Remediation System (TWRS) is one segment of the environmental restoration program at the Hanford site. The scope is to retrieve the contents of both the single shell and double shell tanks and process the wastes into forms acceptable for long term storage and/or permanent disposal. The quantity of radioactive waste in tanks is significantly larger and substantially more complex in composition than the radioactive waste stored in tanks at other DOE sites.

The waste is stored in 149 single shell tanks and 28 double shell tanks. The waste was produced over a period from the mid 1940 s to the present. The single shell tanks have exceeded their design life and are experiencing failures. The oldest of the double shell tanks are approaching their design life. Spare double shell tank waste volume is limited.

The priorities in the Board's view are to manage safely the waste tank farms, accelerate emptying of waste tanks, provide spare tank capacity and assure a high degree of confidence in performance of the TWRS integrated program.

At its present design capacity, the glass vitrification plant (HWVP) will require a period of about 15 years to empty the double shell tanks; the addition of the waste in single shell tanks adds another 100 years.

There is an urgent need to initiate now a well focused and centralized development and engineering program on both larger glass melters and advanced separations processes that reduce radioactive constituents in the low-level waste (LLW). This effort should be part of a central management function on integrating the TWRS program.

The Board presents its conclusions and has other suggestions for the management plan. Included are comments on the Leadership Council TWRS Alternatives and Evaluation Criteria which includes input from the Stakeholders and a number of issues. The Board reviews planning schedules for accelerating the TWRS program. 


\section{BACKGROUND}

The Tank Waste Remediation System (TWRS) is part of the Hanford Environmental Restoration Program. TWRS has a number of functions under three major operations (1) management of waste tanks, (2) processing of tank waste and (3) management of system generated waste and excess facilities.

The management of waste tanks includes interim storage, waste characterization, waste retrieval and transfer of waste to processing. Processing of tank waste includes conversion of waste into acceptable forms for storage and/or permanent disposal. It may also include the separation of the waste into low-level and high-level radioactive fractions prior to conversion. The third major operation covers actions to prepare and certify waste and excess facilities for transfer to other interfacing mission areas. The TWRS functions and the interfaces are shown in the attached WHC chart, Figure II-1, and Figures 5 and 6 found in the Status Report of the Board's January 1821, 1993 meeting.

The DOE and WHC are in the process of preparing a New Technical Strategy for the TWRS to be selected after a study of several alternatives. The new strategy addresses an expanded TWRS that adds all single shell tanks to the current double shell tank program.

In October 1992, WHC formed a Sंystems Engineering Technical Advisory Board (SETAB) to assist WHC by evaluating the TWRS program for safe management and ultimate disposal of Hanford tank waste. Information pertaining to the background and experience of the Board members is provided in Appendix A. The Board in assisting WHC on selecting a new TWRS technical strategy was to maintain an independent viewpoint and to give full consideration to technical, environmental, regulatory, economic, and public concern issues. The Board's schedule was established to complement the WHC's effort to complete the New Technical Strategy selection by April 1. 1993. 


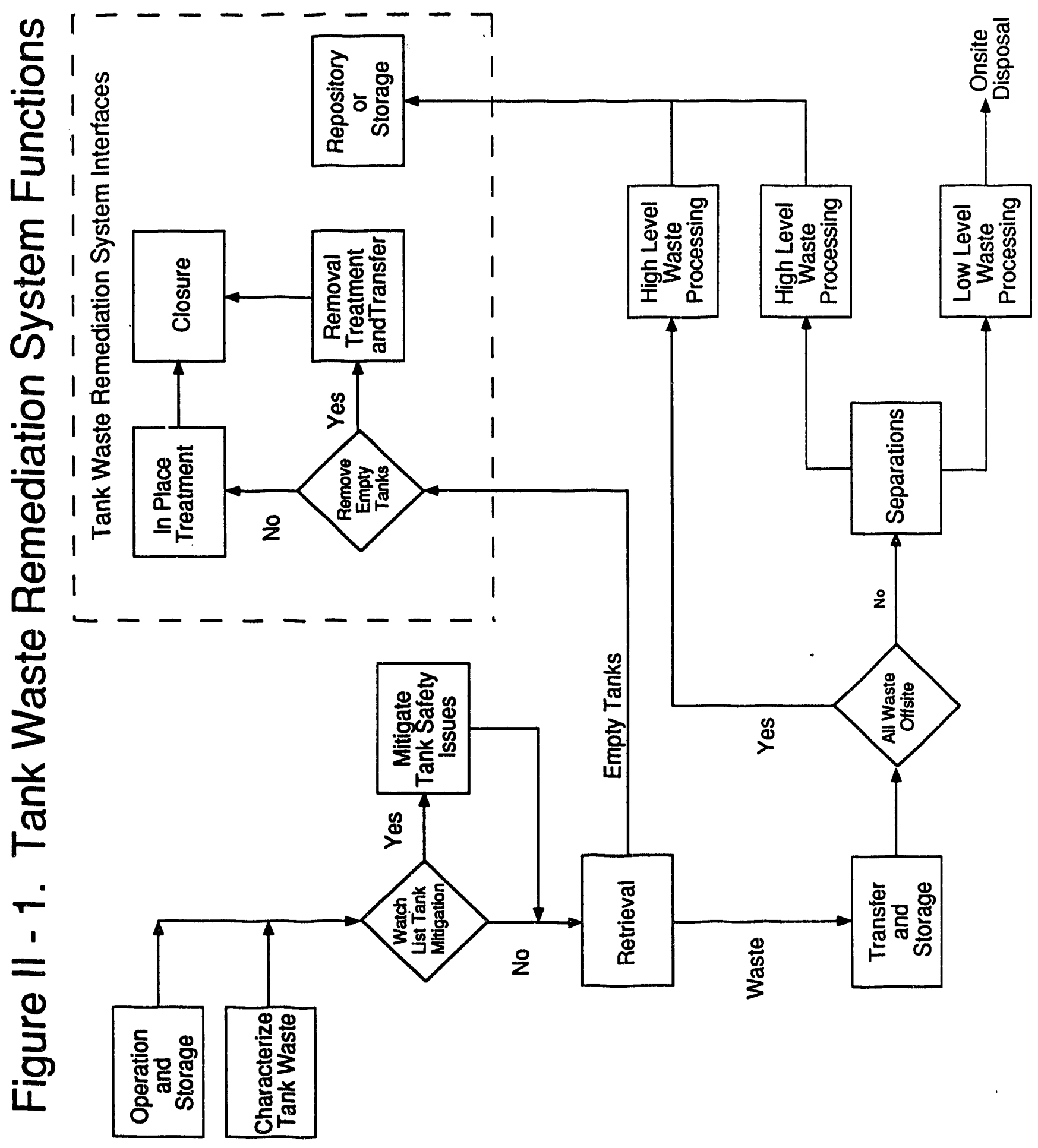




\section{REVIEW}

The Board met three times at Richland. Status Reports describing the results of each meeting are included in the Appendices. Some members of the Board were involved in two other meetings at Richland. Four members attended a meeting on selected topics in early January before the final Board meeting later in the month and two members participated in a meeting of the Leadership Council in early February.

The Board received briefing material on the TWRS program, requested additional data and had access to a number of independent technical, management and safety review documents on the Hanford TWRS program. The Board also reviewed the Tri-Party Agreement.

The first two meetings were used primarily to give all Board members a current and common understanding of the scope of the TWRS program, technology, background on major issues, EIS status, processing alternatives and WHC criteria for the evaluation of alternatives.

The October meeting resulted in a list of briefing topics for the December meeting. The need for two new criteria, operability and technology maturity, and a simplified method for assessing technology maturity were discussed during the October meeting. The Status Report for this meeting is attached.

The December meeting covered some of the major TWRS considerations such as safety, acceleration of tank clean-up, technical feasibility, need for an operating (management) plan, NEPA, and performance measures (criteria). The Alternatives and criteria were still evolving at the time.

During the early January meeting in Richland, the members prepared preliminary development and facility schedules for comparing the current program with alternatives for accelerating the TWRS program.

At its January meeting the Board was requested to rank a number of TWRS alternatives using criteria and weight factors developed by the Leadership Council with input from the Stakeholders. In addition, the Board was asked to rank the same alternatives using the Board's 
own criteria and weight factors. The main difference between the two sets of criteria and weight factors was the Board's heavy emphasis on both operability and technology maturity to assure high confidence in the successful performance of the TWRS. A brief description of the alternatives is contained in Table III- 1 .

The Board members were also requested to provide their views on any aspect of the TWRS program. These views were to incorporate the Board's experience in operating and managing large, complex programs involving radioactive materials. The Board was also to comment on the adequacy of the data.

In addition to ranking processing alternatives during the January meeting, the Board established its views on objectives and approach to accelerating the TWRS program. They are presented in the Status Report for the January 18-21, 1993 meeting, attached as Appendix B-3.

The Board also reviewed some unresolved program elements pertinent to developing the scope and content of the TWRS program. WHC requested comments on some program elements in addition to those selected by the Board. The program elements reviewed are: Decision Analysis Model, Compact Processing Unit Concept, Melter for High Throughputs, Waste Processing Logistics, Organic Destruction, Shipping A High-Level Waste Concentrate to Savannah River, TWRS Interfaces, Acceptance Criteria, High-Level Waste Repository, Contact Maintained Melter for Low-Level Waste, and Ground Water Recharge Rates. Comments on these program elements are in Appendix B-3 (pp. 48-56).

The conclusions were finalized following submission of the Status Report on the January 18-21, 1993 meeting. 
Review

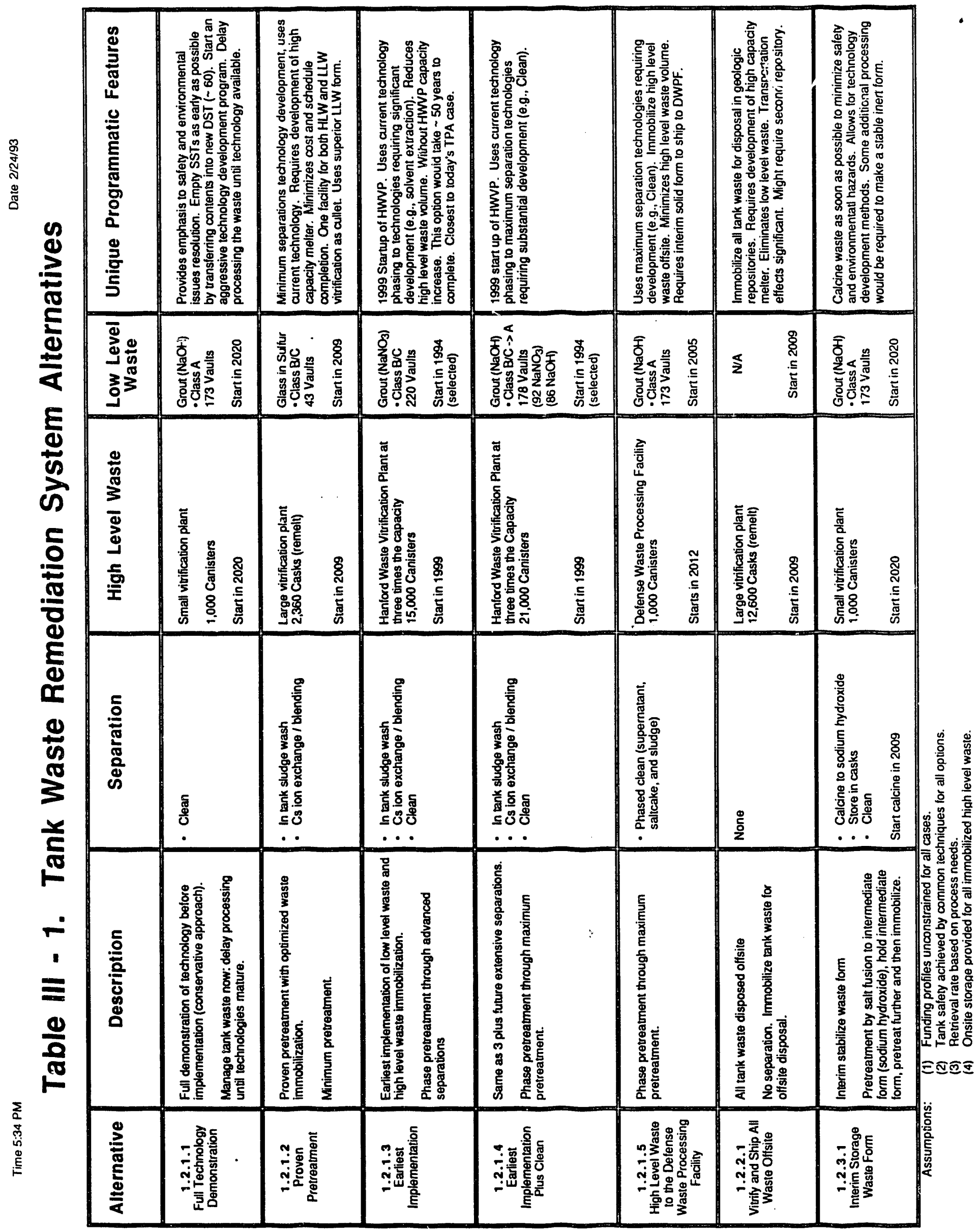

Page 8 


\section{CONCLUSIONS}

The program for emptying tanks must be accelerated.

- The single shell tanks are beyond their design life and are experiencing failures. The oldest of the double shell tanks are approaching the end of their design life.

- The current program is unacceptably long with a completion date sometime in the 22 nd century.

- The piping infrastructure for transferring tank waste should be scoped and scheduled to complement the balance of the program.

The schedule for the current and accelerated program completion is controlled by . the development axd engineering schedule.

- This schedule relationship has existed for a number of years emphasizing the urgent need for priority attention to this part of the management program.

- The technologies with the shortest development schedules and best chance of success should be emphasized.

A well focused development and engineering program should be initiated now.

- The program should employ more than one technology path for the development and engineering program to manage risk until the most promising technology path is apparent to assure success of the overall TWRS program.

- The program should provide technology redundancy for critical steps to avoid delays in selecting the best path; probably in the late 1990s.

- The program should provide the transition from near-term to long-term deployment of the TWRS.

- The program is required to firm up the TWRS schedules for planning the balance of the program. 
- Alihough glass melters are presently used in HLW processing elsewhere, the composition and volume of Hanford waste requires a substantial development effort on higher capacity melters for radioactive service. This effort must include consideratiouns of design and engineering. The glass melter effort can build on the experience with small melters in radioactive waste service and on large melters used in the commercial glass making industry.

- A higher capacity melter program would also support capacity increases in the HWVP.

- Advanced separations development may be incorporated into the selected technology path in the late 1990's in whole or part depending upon the degree of success in the development and engineering efforts.

- All of the new technologies require hot-pilot plant demonstrations before being committed to plant designs.

- The accelerated TWRS program has a reasonably short finite life. After the decision is made in the late 1990s on which technology path to pursue, there is no reason for continuing with alternative technology advances.

There is an urgent need for a centralized integrating management function for execution of the TWRS program.

- There is currently a number of unresolved issues and many more are to be expected to occur in a program of this magnitude, complexity, public visibility, time duration, high level of funding and where responsibilities of organizations outside DOE are impacted by the DOE program.

- The management activities should cover the full range from DOE-Headquarters to DOE-Field Offices and contractors with established clear lines of responsibility, accountability and authority.

- The NEPA process needs to be on a fast track since full commitments follow the Record of Decision. The development 
program would be convistent with the timing in the NEPA process.

- The current focus on near-term budget problems as well as the change in long-term planning requires that the benefits of the currently planned facilities in both the near-term and longterm be evaluated. These include the HWVP, Initial Pretreatment Module, Grout Vaults, etc.

- Ranking of alternatives using generalized criteria with varying levels of data base validity is a useful technique to obtain Stakeholders opinions, but it should not be considered as a substitute for engineering analysis and application of engineering and operational judgment.

- The "Lessons Learned" from both successes and failures in facility design and operations within and outside DOE should be reviewed for use by the organizations in the program.

- An important objective during the development and demonstration program is to obtain sufficient data to assure high confidence in the operating success of the TWRS.

The present data base is adequate to establish a management program and to initiate major programmatic decisions.

- The alternatives defined by the Leadership Council cover a sufficiently broad set of options: advanced technologies, varying LLW forms, shipment of all waste off-site, and vitrification of HLW concentrate at Savannah River (DWPF).

- All of the alternatives employ vitrification at Hanford except the alternative of shipping an intermediate waste form to Savannah River for vitrification.

- The extensive data presently available support the initial major steps that need to be taken now; initiation of a well focused development program, re-evaluation of currently planned facilities, etc. 
- The schedule of technology and engineering development provides the time to do the re-evaluation work without impeding progress on the TWRS program. 


\section{APPENDIX A}

The members of the Systems Engineering Technical Advisory Board are senior individuals with expertise that includes waste treatment, waste tank safety, remediation, and environmental restoration, project management, research and development, facility design, and facility operation. Experience of the individual Board members is summarized below:

\section{Erank P. Baranowski. Co-Chairman}

Frank Baranowski was the Director of Production and Nuclear Fuel Cycle under AEC and later ERDA. In this capacity, he directed government nuclear fuel cycle activities and production of nuclear materials to meet defense, non-defense and commercial requirements of the Agency. The responsibility required integrated management of programs covering the nuclear materials production and fuel cycle activities under federal responsibility. These programs included: evaluation of uranium resources and capability; enriched uranium production for use in weapons and in defense, production, research and commercial reactors; production of reactor products for defense and non-defense customers; research and development for production programs including government supported commercial fuel reprocessing; radioactive waste management; geologic programs for waste disposal; and nuclear materials management. Responsibilities included headquarters level planning, budgeting, development of construction schedules, and overall operations. The operations were at a number of major ERDA sites. Since 1977, Mr. Baranowski has been a management consultant in nuclear and supporting activities. Mr. Baranowski recently participated in two major DOE integration studies; Reconfiguration of the Weapons Complex and Management of HEU Returns from Stockpile. In the HEU Study, Mr. Baranowski was involved with programmatic, policy, economic (near and long-term), institutional and technical issues in uranium enrichment operations, nuclear fuel cycle, tritium and HEU requirements, long-term storage of spent fuel, repository waste forms, shipments and the HLW repository. Mr. Baranowski was a member of DOE's Energy Research Advisory Board (1983-1987), Committees on a New Production Reactor and a Panel on Accelerator Production of Tritium. 


\section{Samuel J. Beard}

Sam Beard has successfully managed a variety of high technology nuclear fuel cycle activities. During his Hanford tenure, he managed research and development programs including technology development for the original Hanford Waste Management Program, irradiated fuels reprocessing, radionuclide recovery, and safe disposal of wastes and effluents. He was later responsible for providing process engineering and process control services to the PUREX Plant, Waste Management Plants, Plutonium Finishing Plant and other 200 area operating facilities. His last Hanford assignment was Manager of Manufacturing responsible for all activities in the 200 Areas. Mr. Beard joined Exxon Nuclear Company in 1971 as Manager of Fuel Reprocessing Engineering responsible for Exxon Nuclear's technical initiatives in commercial nuclear fuel reprocessing. Following subsequent senior management assignments in Exxon's Atomic Vapor Laser Isotope Uranium Enrichment Development Program, he headed the Engineering and Technology Department and Marketing Department before becoming President, Chairman of the Board, and Chief Executive Officer in 1986. Mr. Beard's professional activities included: serving as a U.S. representative to an IAEA symposium on radioactive waste disposal; chairing the AIF's Sub-committee on Radioactive Waste; serving on a radioactive waste disposal advisory panel to the Office of Science and Technology Policy; receiving an Alfred P. Sloan fellowship at MIT; and being awarded the Robert E. Wilson award in Nuclear Chemical Engineering.

\section{James P. Duckworth}

James Duckworth has extensive experience at Hanford in the operation of the PUREX Plant beginning at its startup in the mid1950's. He was Technical Services Manager/Plant Manager/Plant General Manager during most of the period of operation of the West Valley commercial fuel reprocessing plant. He was Technical Assistant to the Vice President and Manager of Production at Idaho with oversight responsibility on the Chemical Processing Plant, the Waste Calciner, and other process facilities. Mr. Duckworth's expertise includes reprocessing, High and Low-level radioactive and hazardous waste management, radiation and nuclear safety, environmental and natural phenomena interfaces, transportation and storage of nuclear materials, and decontamination and decommissioning. Since retirement in 1990 , Mr. Duckworth has 
served on the Technical Review Group for the evaluation of the Defense Waste Processing Facility and West Valley Demonstration Project Waste Qualification Reports and on the Technical Oversight Board for the Red Team Independent Technical Reviews at Hanford and Savannah River.

\section{Claude B. Goodlett. Co-Chairman}

Claude Goodlett has 35 years of experience at the Savannah River Plant in developing and operating processes and equipment for the reprocessing of irradiated fuel; evaporation, storage and permanent disposal of radioactive waste; production and dissolution of thoria; storage of power reactor spent fuel; and the production of high density uranium oxide. His experience includes design, construction and supervision of equipment and facilities similar to those planned for the TWRS. At Savannah River he participated in defining the corrosion and other technical limits for ensuring safe storage of radioactive waste in tanks. He performed the research and development work to define process and equipment parameters for the concentration and transfer of waste including the development and procurement of pumps for dissolution, suspension and removal of waste sludges from the storage tanks and for blending the radioactive waste to be fed to the Defense Waste Processing Facility. Mr. Goodlett has authored and presented papers on many aspects of handling and processing radioactive fuel and radioactive waste. Since retiring from Savannah River in 1989, he has worked as a consultant. While working for the Los Alamos National Laboratory, he was a member of three "Red Teams" that were charged with reviewing the technical aspects of the present and proposed programs for handling and solidifying the high-level waste at Hanford. He was a member of the Phenomenology or Process Engineering Subpanels during each of these reviews and Leader of the Phenomenology Subpanel during the last review of the Hanford tank farm operations.

\section{Dr. Alfred Schneider}

Dr. Alfred Schneider has a broad background in the nuclear fuel cycle with special expertise in process development and design of nuclear fuel reprocessing and waste management facilities. His areas of interest and expertise are technology, economics, safety and environmental aspects of the nuclear fuel cycle, separations methods for isotopes, and design of nuclear fuel cycle facilities. Dr. Schneider 
is currently a consulting engineer and Visiting Professor of Nuclear Engineering at the Massachusetts Institute of Technology. Previously, he was a professor at Georgia Institute of Technology. Dr. Schneider has had a long career in the private sector. He was Director of Nuclear Technology for Allied-General Nuclear Services during the development, design, and construction of the Barnwell Nuclear Fuels Plant. Prior to that, he managed the development of materials and processes for the production of isotopic heat sources at Martin-Marietta Corporation and conducted research in radiation chemistry and pyroprecessing of breeder reactor fuel at Argonne National Laboratory. He has recently consulted to the U.S. Department of Energy, the U. S. Congress-Office of Technology Assessment, and Westinghouse Electric Corporation, and has served on many panels reviewing nuclear processes and programs. Dr. Schneider has been a member of the Hanford Waste Management External Advisory Committee since it was formed in 1991 and the Secretary of Energy's Advisory Board (Radioactive Waste Management Tank Force) since 1991. He received the Robert E. Wilson award from the AIChE and the Antarctica Medal from the U.S. Navy.

\section{Lyle L. Zahn}

Lyle Zahn has a broad background in the nuclear fuel cycle with special expertise in the design and operations of nuclear fuel cycle facilities. He was manager of the Hanford PUREX Plant and, later, director of the PUREX restart program of 1980-83. He was Manager of Nuclear Diversification for Atlantic Richfield which included their technical initiative into commercial nuclear fuels reprocessing; the plant conceptual design and safety analysis report were prepared during this period. He was manager of the General Electric Midwest Fuel Reprocessing Plant during its successful reconfiguration to fuel storage. He was manager of several successful high technology projects, both nuclear and non-nuclear, which progressed from technology development through to plant operations. He was a member of the U.S. delegation to the International Atomic Energy Agency on international spent fuel shipping regulations and a costfree expert to the IAEA on safeguards for a heavy water production plant. He was technical-lead on the PUREX Deactivation Red Team. Since 1989, Mr. Zahn has been a private consultant to the nuclear industry. 


\section{APPENDIX B}

Following each meeting, the Board prepared and submitted to the Westinghouse Hanford Company a Status Report summarizing the activities that occurred during the meeting. These Status Reports are attached as Appendices B-1, B-2 and B-3. Appendices B-1, B-2 and B-3 provide detailed information about the topics summarized in the main body of this report. 


\section{APPENDIX B-1}

November 3, 1992

To: John Garfield, Westinghouse Hanford Company

M. K. Korenko, Westinghouse Hanford Company

From: Sytems Engineering Technical Advisory Board for the Tank Waste Remediation Program

\section{STATUS REPORT}

As requested, we have prepared a brief status report on our activities at the October 27-29, 1992 meeting held at Richland. A second meeting of the Board is scheduled for December 7-9, 1992 at Richland. Members of this Systems Engineering Technical Advisory Board for the Tank Waste Remediation Program are given in Attachment 1. A copy of your slide defining the charge to the Board is shown 's Attachment 2.

The Board members would like presentations and discussions during the next meeting on the topics given in Attachment 3. We suggest the addition of an eight item, Operability, to the seven performance measures presently being considered in the study. This addition results from the operating experience of the Board members. The eight performance measures are given below:

Environmental
Public Health
Occupational Safety
Regulatory Compliance
Technical Feasibility
Schedule
Life Cycle Cost
Operability

We would also like to see a technology maturity assessment for the various process steps similar to Attachment 4. Presentations on (1) the methodology that will be used to select a limited set of alternatives for further evaluation and (2) the Draft Notice of Intent for the Tank Waste Remediation System Environmental Impact Statement will also be helpful. 
It is apparent that input from groups other than the Department of Energy and the Westinghouse Hanford Company could have a significant effect on the evaluation of options chosen for study. The Board will concentrate its review on areas such as technical feasibility, costs, safety, operability, etc. Our involvment in non-DOE areas will be based on guidance by the Westinghouse Hanford Company.

We will keep you advised of questions raised by Board members and any additional information needed by the Board members. This information could include copies of reports, presentations and discussions at later meetings.

The Board would like to commend you and your staff for the program presenting material from the "Tank Waste Systems Engineering Study," WHC-EP-0405 (presently titled "Tank Waste Technical Options Report", WHC-EP-0616) and its presentation at this first ineeting and look forward to continued interaction with you and your staff.

CC: Board Members 


\section{ATTACHMENT ONE}

SYSTEMS ENGINEERING TECHNICAL ADVISORY BOARD MEMBERS

Frank Baranowski, Co-Chairman

Claude Goodlett, Co-Chairman

Sam Beard

Jim Duckworth

Alfred Schneider

Lyle Zahn 


\section{ATTACHMENT TWO}

CHARGE OF THE SYSTEMS ENGINEERING TECHNICAL ADVISORY BOARD

1. Become knowledgeable in the elements of the TWRS program

2 Provide and independent review and validation of alternatives assessment

- examine and validate criteria requirements

- examine and validate the performance measures

- review the engineering basis for the alternative assessments

- review the decision analysis model

3. Make recommendations for improvements as necessary

4. Review and critique the process for evaluation of the alternatives 


\section{ATTACHMENT THREE}

REQUESTED TOPICS FOR THE SYSTEMS ENGINEERING TECHNICAL ADVISORY BOARD MEETING FOR DECEMBER 7-9, 1992

Options - Optimize

New Options

Screening Criteria Applications

- Availability of Chemicals for Process

Performance Criteria Application

- Promising Options

- Issues

- Risks

- Non-DOE input

Technology Maturity and Operability Criteria

Research and Development Requirements

Schedules - Timing - 5-Year Plans

Environmental Impact Statement

Defense Nuclear Facility Safety Board

Environmental Health Review

Characteristics of Waste 
ATTACHMENT FOUR

\section{TECHNOLOGY MATURITY ASSESSMENT}

Process A Process B Process X, etc

Cold. Bench Scale

Studies

Cold Bench Scale

Demonstration

Hot Bench Scale

Demonstration

Cold Pilnt Scale

Demonstration

Hot Pilot Scale

Demonstration

Production Scale Use

Conventional Industry

Nuclear Industry 


\section{APPENDIX B-2}

January 6, 1993

To: J. S. Garfield, Westinghouse Hanford Company

M. K. Korenko, Westinghouse Hanford Company

H. D. Harmon, Westinghouse Haniord Company

D. J. Newland, Westinghouse Hanford Company

From: Systems Engineering Technical Advisory Board for the Tank Waste Remediation Program

\section{STATUS REPORT}

We are submitting a status report on our activities following the December 7-9, 1992 meeting of the Systems Engineering Technical Advisory Board for the Tank Waste Remediation Program held at Richland. All Board members were present at this meeting except Alfred Schneider was unable to attend due to illness. A third meeting of the Board is scheduled for January 18-20, 1993 at Richland. As discussed with John Garfield four members of the Board plan to visit Richland January $11-12,1993$ to meet with members of the Westinghouse Hanford Company to discuss the methodology used to rate the various options as well as other topics.

Views of the Board members that were presented to John Garfield, Harry Harmon, and Denny Newland orally on Wednesday morning, December 9, 1992, are included. As expected from a Board that has as brcad a range of experiences as this group, there are differing opinions as how we can best respond to the charter to assist the Westinghouse Hanford Company in their mission. Since the Board has not met as a group since the December meeting to discuss these differences, we are attaching essentially two status reports, Attachments 1 and 2, that span the opinions of Board members. Rather then hold up the report, we are serding it without discussion at a meeting attended by all Board members. This is a preliminary status and is subject to change in the final report.

The Board prepared a charter defining its understanding of its responsibilities. This charter, Attachment 3, lists specific outputs for lie report based on information presented at the first meeting by John Garfield and Mike Korenko, presentations and discussions during the two Board meetings, review of a number of recent reports 
during the two Board meetings, review of a number of recent reports on the Hanford TWRS, and other revelant data. This charter states that the Board will review the list of options being considered for the TWRS and the methodology being used to appraise these options and suggest any additions or modifications to these studies. The Board does not plan to select or recommend a specific option. The specific outputs from. the Board will be reviewed with WHC before preparation of the final report.

CC: Panel members 


\section{ATTACHMENT 1}

\section{SELECTION PROCESS}

The options from which the selection of the baseline integrated system should be made, must clearly address the major considerations that have been raised over a number of months. In the meetings of this Board and in reports issued previously by other groups on topics such as safety, technical, operating, and policy issues have been addressed in detail. Some of these major considerations are:

\section{- Safety}

In the investigation of safety issues there should be an effort identified in the program plan that emphasizes the investigation of actions that would accelerate cleanup of the waste tanks. The tank contents, or wastes, need to be removed from the tanks as soon as practicable since the design life of many SST tanks has already been exceeded. Additionally, the design life of the double shell tanks may be approached or exceeded before they can be emptied. The efficacy of low-temperature in-tank digestion of organics should be accelerated in the laboratory.

Accelerate Tank Clean-up - Capacity of the HLW Solidification Eacility

Increasing the processing rate of the HLW solidification facility has been discussed as a way to accelerate the schedule for emptying the waste tanks. The analysis of a higher capacity solidification facility must consider not only technical feasibility but must include operability factors such as the expected life of the facility, the age of the waste tanks, equipment selection and availability, and the ability of the supporting facilities to supply feed to the solidification facility. Also of prime importance is the final HLW waste form and its acceptability at the repository. The reduced set of options should address the acceleration of the program to remove the waste from the tanks with the accompanying development and testing programs.

These are major issues that have review and acceptance requirements both within and outside DOE. Operating plans 
should include spare DST tank capacity and schedules for waste characterization coordinated with facility plans. The waste tank safety issues should be resolved as soon as practical. The Board was told that the IPM could be constructed to expedite resolution of safety problems. The selection of a reduced set of options should consider the solutions to safety issues with and without an IPM.

\section{- Technical Feasibility}

There is a range of technologies that have been proposed by WHC and DOE. These technologies have different levels of maturity. The Board suggested at its first meeting that a new performance measure on operability be added to the seven performance measures being used by WHC. WHC has added operability as a performance measure. There are at least three major discriminators - time, risk of performance (operability), and safety. These discriminators must be considered in the final group of options. The maturity and operability tables prepared by WHC will be built on the technology data base to be used in the selection process. Additional work to be done on all processes under consideration should be treated in the evaluations.

The reduced set of options should compare the mature technologies with selected advanced technologies. Back-up technologies should be considered for those processes that have not been demonstrate in production scale equipment. The technology effort and time to provide hard data for a decision should be presented. The expected benefits and limitations of the technologies need to be stated. Since technology is constantly changing, there will always be the new promising technology on the horizon which encourages procrastination and delay. Advanced Technology must go through a development and demonstration period before it becomes established resulting in a delay for a decision.

Only Established Technology available at the time a decision is made to proceed should be considered for Title I and Title II design and eventual deployment for the TWRS mission. The Board views Established Technology as technology that has been at least demonstrated in hot pilot scale equipment and preferably in plant scale equipment. Choosing processes that are 
still under development present unacceptable risks that could result in increased program cost, schedule delays and program failure. During Title I and Title II design, development funds should be used to optimize the selected technology and to demonstrate technology in cold plant scale equipment that has been carried through hot pilot scale demonstrations. Early procurement of the most complex plant equipment for mockup and cold testing in parallel with plant construction reduces risks at startup.

In reducing the set of options, it is necessary to consider the trades that must be made in weighing the benefits and risks of the earlier dates of tank farm closure against projected benefits and risks for alternative integrated options.

The selection process must include all of the key elements of an accompanying integrated operating plan to fully address the major considerations. This must be done to insure that coverage and schedules for integration of construction, operations, technology and test program, laboratory support, etc. are sufficient to effectively close the waste tank farm system Specific examples are the operating plans for tank sampling, the management of spare tank capacity, and the complete emptying of tanks (capacity of the HLW solidification facility). The DOE decision maker must be assured that the selection process used for the decision is supported by a coordinated and feasible construction and operating effort within WHC and throughout DOE.

The Program Plan should be developed concurrently with the selection process. The Program Plan should include the Technology Plan together with plans, resource requirements, contingency provisions, and schedules for all other program activities. The Program Plan should also consider the restraints, timing, and strategy for NEPA compliance.

The selection process should not rely exclusively on Decision Analysis and a simple nimerical ranking.

\section{NEPA}

The TWRS system definition and its boundaries to be used by WHC and this Board must be consistent with the one chosen for the NEPA process. Otherwise, the data base to be used by the Board in its 
review will not be the same as for the NEPA process. It is important to have the NEPA TWRS system definition since the TWRS is part of a broader strategy and interacts with other systems. For example, the option of shipping the waste to Savannah River for solidification in the DWPF expands the boundaries outside Hanford (beyond the repository interface) and raises questions on technical feasibility because of the different and more complex composition of the Hanford tank waste. The packaging and shipment of radioactive waste across the country are considered to be major considerations that, to some extent, are policy in nature.

Since the NEPA process must be completed before a decision on the TWRS integrated system can be made, the date for the ROD appears to fix the commitment date for completion of all analyses and selection of the TWRS integrated system.

\section{PEREORMANCE MEASURES}

The Board has reviewed the seven "Tank Waste Remediation System Performance Measures" and generally concurs that these are the criteria that should be considered in evaluating the TWRS options and alternatives. The first two, "Environment" and "Public Health" will likely be affected most by the timelines with which the program is executed. Degradation of the existing tanks and ancillary facilities during any delay must be compared with potential benefits projected from technological developments achieved during the delay.

The Board proposes adding an Operability Performance measure which should include consideration of potential plant accidents, maintainability of the facilities and equipment, the tolerance of the process and system to variations in process parameters, and the overall complexity of the process and equipment.

The Board suggests that the System Performance Measures be weighted in accordance with their importance to the overall program success. For example "Operability" should receive a high weighting because if the plant will not operate, the merits of the other performance measures are not important. Compliance with all laws and regulations for environmental protection, public health, occupational safety, and regulatory compliance, health, safety, and environment must be common for all selected processes. 


\section{ATTACHMENT 2}

The Board believes that the 'Preferred Alternative' should be identified and implemented soon in view of the urgency to deal with the single shell tanks. Most of the information required for the selection of the preferred alternative is already available in the Tank Waste Systems Engineering Study. Since the Technology Plan and the Technical Strategy have not been published yet, the Panel has not been able to review specific technology development plans. The Board believes that an aggressive development plan be established around the Preferred Alternative with clearly defined resource requirements, milestones, and schedules as part of an overall Program Plan for the TWRS. Obviously, these efforts should be adequately funded. Efforts and funding should be concentrated on the Preferred Alternative and not diverted to far-fetched alternative technologies or potential facilities. However, the Preferred Alternative should be backed up, prudently, with a contingency plan to protect against unfavorable developments in the Preferred Alternative.

\section{Technical Strategy}

It is important to expeditiously narrow the field and focus resources on a minimum number of alternatives. The Preferred Alternative can be identified from information available in the Tank Waste Systems Engineering Study (presently titled Tank Waste Technical Options Report) using the Selection Criteria discussed below.

The Program Plan should be developed to implement the Preferred Alternative as soon as possible. The Program Plan should include the Technology Plan together with plans, resource requirements, contingency provisions, and schedules for all program activities. The Program Plan should also consider the restraints, timing, and strategy for NEPA compliance.

\section{Selection Criteria}

The following criteria should be applied to the selection of the Preferred Alternative:

- The waste tank safety issues should be resolved as soon as possible, without waiting for the IPM. The efficacy of low- 
temperature, in-tank digestion of organics should be ascertained in the laboratory promptly.

- The single shell tanks should be emptied as quickly as practicable and on a prioritized basis with cyanide-bearing waste first. Since downstream processing capacity should match the waste retrieval rate in order to minimize the capital outlay for new waste tankage, this implies high capacity waste processing systems, on the order of hundreds of tonnes per day throughput.

- The high level waste product, destined for shipment offsite, should meet the Waste Repository specifications for borosilicate glass.

- The candidate processes should be evaluated on the following criteria in selecting the Preferred Alternative:

Technical Maturity, Ideally, the process should have been proven in actual plant operation. The only function in which this criterion can not be fulfilled is in the high-capacity processing of waste into glass. An aggressive, near-term development program is needed to provide a reliable, highcapacity melter.

Qperability. The process should be simple and inherently safe to operate.

Safety, Overall safety characteristics should be favorable.

Cost.

\section{Schedule.}

The other performance measures considered in the Systems Engineering Study (presently titled Tank Waste Technical Options Report) including environmental protection, public health, occupational safety, and regulatory compliance do not enter directly into the selection process since they are mandatory to all alternatives. 


\section{ATTACHMENT 3}

\section{Charter of The Systems Engineering Technical Advisory Board}

- Provide an independent review of the alternative assessment and selection processes for the TWRS integrated system.

- Review and critique the performance measures (criteria) used in the Tank Waste Remediation Systems Engineering Study and recommend charges and additions to improve the assessment of options and alternatives.

- Review the bounding restraints to the TWRS program and their effect on the selection process.

- Review the TWRS program and its relationship to other Hanford programs. Become cognizant of other recent reviews of the tank farms and related facilities.

- Perform a detailed review of the TWRS functions and options within each function. The panel will identify those functional options which lack merit for continued consideration.

- Consider the thoroughness of the technology base and the practicality of deploying the various processes in a radioactive environment including operability aspects.

- Consider the timing constraints of $R \& D$ requirements for the various candidate processes in assessing their technical feasibility.

- Develop an understanding of the candidate functional options including their implications on capital and operating costs, end product characteristics, terminal site conditions, and other performance measures. 


\section{APPENDIX B-3}

February 3, 1993

To: J. S. Garfield, Westinghouse Hanford Company

M. K. Korenko, Westinghouse Hanford Company

H. D. Harmon, Westinghouse Hanford Company

D. J. Newland, Westinghouse Hanford Company

From: Systems Engineering Technical Advisory Board for the Tank Waste Remediation Program

\section{STATUS REPORT}

We are submitting a status report documenting our activities at the January 18-21, 1993 Richland meeting of the Systems Engineering Technical Advisory Board for the Tank Waste Remediation Program. This was the third meeting of the Board. As requested two members of the Board, Sam Beard and Claude Goodlett, will represent the Board at the second meeting of the TWRS Leadership Council scheduled for February 4-5, 1993 at Richland.

The first day was spent bringing the full membership up to-date on the previous week's meeting, January $11-13,1993$, at Richland which was attended by four members of the Board and to review with WHC the items that they would like the Board to address during the balance of the meeting. WHC requested that the Board (1) rank the TWRS alternatives using the performance measures agreed to at the Leadership Council meeting and expanded by WHC, (2) use the Board's performance measures to rank the alternatives, (3) present to WHC management comments on any aspect of the program, and (4) assess the quality of the data used in the TWRS studies.

The Board's rankings of the alternatives and the Board's response to the WHC management questions were presented on the last day of the meeting. Due to other committee commitments, Alfred Schneider was unable to attend this presentation.

The following summarizes the views of the Board and generally follows the order of the presentation to WHC management. A final report will be issued by the Board. 


\section{EXECUTIVE SUMMARY}

The Systems Engineering Technical Adviscry Board met at Richland three times to attend briefings and to engage in discussions on the many elements of the TWRS program. The Board received briefing material and requested supporting and additional data, obtained copies of a number of review team reports which included DOE-Red Team Independent Technical Reviews, copies of Defense Nuclear Facility Safety Board correspondence and a DOE-EH safety review.

In response to a specific request of WHC, the Board ranked alternatives using the Leadership Council Criteria and the same alternatives using its own criteria. In addition, the Board was requested to provide its views on any aspect of the TWRS program which would incorporate its experience in operating and manaing large, complex programs involving radioactive materials.

The rankings using the Leadership Council Criteria at Level 2 and Level 3 gave the highest score to those alternatives that ended with the LLW and HLW in a glass form. In using its own criteria and weights the same two alternatives also scored the highest. The Board places high weight on performance (operability and technology maturity) of the integrated facilities not only in producing acceptable LLW and HLW forms but in assuring the facilities meet strict safety, health and environmental standards. The Board also looked at discounted costs. The criteria comparison results are not surprising since the yardsticks for each criterion in either set provided freedom to incorporate the members own knowledge and experience.

The Board places primary emphasis on (1) the early resolution of the waste tank safety issues, uncertainty in tank life and available spare tank capacity and (2) high confidence in performance of the TWRS integrated system. To address these objectives, the Board put together a program overview that displayed schedules of current f-silities planning, representative alternatives and connected the near-term and long-term facilities planning with a development commitment date on selecting advanced technologies. The Board considered an increase in the HWVP capacity to 10 tons per day to advance the completion date of the program, which now includes single shell tank waste, to the 2040s.

This program overview provides guidance on the initial steps to be treated in a management plan and raises specific issues that need 
resolution during the initial phase of program implementation. The alternatives do span the broad range of technical and management issues. WHC provided the Board with criteria generated by the Leadership Council which communicated the views of the Leadership Council as to how the TWRS alternatives should be evaluated.

The development programs control the schedule for program completion and they should be a priority effort. The larger melter is common to all alternatives. The risks in developing larger melters is considered to be lower than development of the full range of advanced separations processes. The decision date for selecting the advanced technologies is the 1998 time frame. The TWRS program does not have a continuing significant mission for new technology once the 1998 decisions are made.

There is need for a continuing central integrating function during the building of the total TWRS program to assure all iequirements are met.

The Board provides comments on a number of issues important to the TWRS program: the compact processing unit (CPU); shipping high-level concentrate to Savannah River for vitrification; melter for high throughputs; waste processing logistics; organic destruction; TWRS interfaces; acceptance criteria for materials crossing TWRS boundaries; HLW repository; and the potential use of a contact maintained melter for low-level waste. The first two do not appear to be viable for further consideration.

The Board's review of the numerous studies, critical issues and scheduling of facilities has led it to the position that the development of advanced technology, primarily the larger melters, is essential to completing the TWRS over a reasonable period of time. It is the Board's judgement that sufficient information is available to take this step now. The issues discussed above and others mentioned in the report should be pursued in parallel with the establishment and execution of the development program.

\section{RANKING OF ALTERNATIVES}

The Board was requested by WHC to rank the TWRS Alternatives using both the criteria and weightings suggested by the Leadership Council and the criteria and weightings developed by the Board. These rankings include consideration of program objectives such as 
emptying of tanks early, resolution of safety issues and high confidence in the success of leading TWRS alternatives.

\section{USE OF LEADERSHIP COUNCIL CRITERIA AND WEIGHTINGS}

The Board ranked the TWRS alternatives using the criteria and weightings suggested by the Leadership Council at Levels 2 and 3, Level 2 is less detailed than Level 3. A brief description of these alternatives at Level 2 with their designation and rankings is given below.

\section{Level 2}

- Separate waste into fractions. HLW fraction immobilized and transferred to repository, LLW fraction immobilized for on-site disposal. Designated as 1.2 .1 .

$$
\text { Ranking }=41 \text { Weighted Average }=100
$$

- Immobilize all waste for off-site disposal. Designated as 1.2.2.

$$
\text { Ranking }=61 \text { Weighted Average }=140
$$

- Treat waste to an intermediate waste form for later immobilization and disposal. Designated as $\mathbf{1 . 2 . 3}$.

$$
\text { Ranking }=36 \quad \text { Weighted Average }=86
$$

The results of this ranking using the criteria and weightings suggested by the Leadership Council are summarized in Table 1 and show that immobilization of all waste for off-site disposal (1.2.2) scored highest.

The Board would like to clearly state that the rankings were based on the knowledge and judgment of the individual Board members. Information supplied by wHC was carefully considered during the Board's deliberations.

The Board also ranked the seven TWRS alternatives using the criteria and weightings suggested by the Leadership Council at Level 3. A brief description of these alternatives with their designation and rankings is given below. 


\section{Level 3}

- Delay processing of tank wastes until technologies mature. Manage tank wastes now. Designated as 1.2.1.1.

$$
\text { Ranking }=37 \quad \text { Weighted Average }=89
$$

- Minimum pretreatment. Designated as 1.2.1.2.

$$
\text { Ranking }=54 \quad \text { Weighted Average }=131
$$

- Phased pretreatment through advanced separations. Designated as 1.2.1.?.

$$
\text { Ranking }=33 \quad \text { Weighted Average }=78
$$

- Phased pretreatmen: through maximum pretreatment; immobilize HLW/LLW fraction on-site. Designated as 1.2.1.4.

Ranking $=35 \quad$ Weighted Average $=77$

- Phased pretreatment through maximun. pretreatment; immobitize HLW/LLW fraction off-site (є.g., DWPF). Designated as 1.2.1.5.

$$
\text { Ranking }=33 \quad \text { Weighted Average }=73
$$

- Immobilize all tank waste for off-site disposal. Designated as $1.2,2.1$.

$$
\text { Ranking }=61 \quad \text { Weighted Average }=142
$$

- Pretreat tank waste to an intermediate form. Store intermediate form for further processing, then immobilize. Designated as 1.2.3.1.

$$
\text { Ranking }=34 \quad \text { Weighted Average }=80
$$

The results of this ranking using the criteria and weightings suggested by the Leadership Council are summarized in Table 2 and show that immobilization of all waste for off-site disposal scored highest and that minimum pretreatment had the second highest score; these two alternatives scored considerably higher than the other five alterratives.

\section{BOARD'S SELECTIOIS_CRITERIA}

The Board prupared its own criteria and weightings based on its experience and judgment. These criteria and weightings are shown in Tabie 3. Eight of the 14 criteria suggested by the Leadership 
Council were used directly by the Board but with different weightings (see Table 3). The Board generated two new criteria, Operability/Reliability and Technology Maturity, which were weighted heavily (see Table 3 ). These two new criteria incorporated, among other considerations, four of the criteria suggested by the Leadership Council, (1) Minimize Time Duration for Resolving Safety Concerns, (2) Minimize Time Duration for Resolving Environmental Concerns, (3) Utilize Simple, Reliable Processes and Systems as Much as Possible, and (4) Provide Maximum Flexibility for Incorporating Improved Technology. Also included in these 2 new criteria was Process Safety; no process should be considered that cannot be operated safely. The Board felt that the Leadership Council criterion of Maximizing Waste Conerersion to Releasable Forms (Criterion 4) was of minor importance and was not ranked. The Board also felt that the Leadership Council criterion of Minimizing Time for Institutional Control (Criterion 7) was governed by areas other than TWRS such as facility decontamination and decommissioning.

The scope and rationale for the individual criteria, and their weightings, are discussed below. The scoring system of 1 to 5 used by the Leadership Council was retained to facilitate direct comparisons with Leadership Council rankings.

\section{OPERABILITY/RELIABILITY}

This criterion encompasses both the selected processes and the facility design. The system should have a minimum number of process steps and adequate lag storage provisions so the processes can operate independently. The system should be inherently safe and environmentally benign, i.e. explosion and fire hazards should be avoided, use of hazardous chemicals should be minimized, temperatures and pressures should be kept as near ambient as practicable, and system designs should anticipate and provide for prompt detection and correction or mitigation of system upsets. This system must comply with all regulations. The system should be simple and straightforward to operate and maintain. The process selection and system design should ensure high, reliable on-stream availability and achievement of operational objectives.

This criterion was given the highest weighting of 5 in consideration of its overall importance to program success. 


\section{TECHNOLOGY MATURITY}

Maturity of the technology is judged by where the proposed process or technology is situated in the hierarchy of development testing and demonstration at the time of process selection:

- Cold laboratory testing complete

- Hot laboratory testing complete

- Cold pilot-plant testing complete

- Hot pilot-plant testing complete

- Production scale demonstrated

The Board believes that the technical maturity of a proposed process or technology should be sufficiently advanced at the time of process selection to ensure its successful and timely application to the TWRS. This means that the process has at least progressed successfully through "Hot" pilot-plant testing. If plant scale-up from the "Hot" pilot-plant is considered to be technically uncertain, as a minimum some combination of "Hot" pilot-plant and full-scale cold testing would be required.

This criterion was also given the highest weighting of 5 in consideration of its overall importance to program success.

\section{PROGRAM DURATION}

This criterion was assigned by the Board to emphasize the urgency of completing the TWRS mission expeditiously. It is sensitive to the timing for the start of development programs as well as the duration of the work.

The Board assigned a weighting of 3 to this criterion recognizing its importance in judging the relative merit of alternatives.

\section{LIFE CYCLE COST}

This criterion is an indication of the total resource requil:ements of each alternative. In addition to the normal life cycle cost evaluation, the Board believes that the total cash flow on a discounted basis should be prepared to reflect the time value of money in comparing the widely different expenditure patterns. However, the lower costs associated with 
discounted cash flows should not be used to justify delaying major expenditures of money at the expense of delaying program completion. Also, the Board believes that the availability of funding should not be ignored in the assessment of funding profiles for the various alternatives.

The Board assigned a weighting of 3 to this criterion.

\section{SAFETY}

This criterion explicitly includes protection of the public and worker from harm or injury resulting from normal operation, off-normal conditions, or accidents.

The Board assigned a weighting of 2 to this criterion on the basis that protection of the public and worker is implicit in the Operability and Reliability criterion.

\section{OTHER ENVIRONMENTAL}

The Board's weighting of 2 for this criterion also considers the implicit environmental concern in the Operability and Reliability criterion.

\section{REGULATORY COMPLIANCE}

The Board assigned a weighting of 1 to this criterion. Compliance with all regulations must be an integral part of the system operation and management.

\section{USE OF SYSTEMS ENGINEERING TECHNICAL ADVISORY BOARD}

\section{CRITERIA AND WEIGHTINGS}

The Board ranked the seven TWRS alternatives using its own criteria and weightings at Level 3. A brief description of these alternatives with their designation and rankings is shown below.

\section{Level 3}

- Delay processing of tank wastes until technologies mature. Manage tank wastes now. Designated as 1.2.1.1.

$$
\text { Ranking }=17 \quad \text { Weighted Average }=43
$$


- Minimum pretreatment. Designated as 1.2.1.2.

$$
\text { Ranking }=28 \quad \text { Weighted Average }=80
$$

- Phased pretreatment through advanced separations. Designated as 1.2 .1 .3 .

$$
\text { Ranking }=17 \quad \text { Weighted Average }=51
$$

- Phased pretreatment through maximum pretreatment; immobilize HLW/LLW fraction on-site. Designated as 1.2.1.4.

$$
\text { Ranking }=16 \quad \text { Weighted Average }=\text { il }
$$

- Phased pretreatment through maximum pretreatment; immobilize HLW/L'W fraction off-site (e.g., DWPF) Designated as 1.2 .1 .5 .

$$
\text { Ranking }=13 \quad \text { Weighted Average }=35
$$

- Immobilize all tank waste for off-site disposal. Designated as 1.2 .2 .1 .

$$
\text { Ranking }=30 \quad \text { Weighted Average }=86
$$

- Pretreat tank waste to an intermediate form. Store intermediate form for further processing, then immobilize. Designated as 1.2.3.1.

$$
\text { Ranking }=13 \quad \text { Weighted Average }=34
$$

The results of this ranking using the criteria and weightings suggested by the Board are given in Table 4 and show that immobilization of all waste for off-site disposal scored highest and that minimum pretreatment had the second highest score. The rankings are the same as obtained when using the Leadership Council criteria and weightings.

\section{METHODS FOR ESTIMATING COSTS}

The Board believes that the present methods of estimating costs in constant dollars for the process options should be supplemented by estimating costs in both (1) discounted dollars using the discounting procedure used by the Department of Energy and (2) cost in the near term (early budget years). These three methods for estimating costs allow the decision maker to look at costs from a variety of viewpoints. Preliminary cost calculations made by WHC using the discounted dollar method are shown in Table 5 along with costs using constant dollars. The use of discounted dollars tends to favor cost 
scenarios where costs are deferred as late as the schedule allows. These discounted costs were not available at the time the alternatives were ranked. Based on cost information supplied by WHC to the Board later, the lowest cost option for either constant dollars or discounted dollars is the minimum pretreatment alternative (1.2.1.2).

The Board is concerned about the accuracy of the cost estimates; typically a process that is less developed will show a lower cost estimate than a process that is well defined. It is well documented throughout the industry that as development work progresses, the cost estimates for facilities to deploy the process increase. Quite often processes that appear simple and therefore less costly increase in complexity and cost as detailed process and design information becomes available.

Another concern of the Board is what is considered in the cost estimates. Do they include ALARA considerations, ability to meet NRC criteria, Operational Readiness Review requirements, and decommissioning costs?

\section{PRESENTATION}

The presentation given to WHC and other interested persons included a listing of objectives and the Board's approach to examining the alternatives followed by suggested actions and conclusions regarding the TWRS program.

\section{OBJECTIVES}

\section{ACHIEVE EARLY RESOLUTION OF THE TANK SAFETY ISSUES}

The independent external reviews by both the Defense Nuclear Facilities Safety Board and the DOE-EH have placed the safety of waste tanks at the top of their priority list requiring resolution. There is a WHC effort on mitigation and resolution of the safety issues. In addition to tank content safety issues there are uncertainties in tank life and the time when adequate spare tankage becomes available. The program for emptying both the SST and DST tanks is prolonged by the limited capacities generated by planned facilities. 
ACHIEVE HIGH CONFIDENCE IN PERFORMANCE OF THE INTEGRATED TWRS SYSTEM

Not only is it necessary to build an integrated TWRS system that has low risks in the production of acceptable LLW and HLW waste forms and meeting criteria at the TWRS boundaries, but the TWRS must also be designed and operated to meet the strict requirements of the safety, health and environmental standards. There are a number of uncertainties that need to be addressed before this objective can be met. The Board has embraced this objective with the Board's criteria to include and emphasize plant operability considerations.

\section{DEVELOP A STRONG MANAGEMENT PLAN}

The alternatives and the unresolved issues 'highlight the uncertainties and the priority work that needs to be part of the management plan for the TWRS program. In addition, the adequacy of the guidance to the program should be assessed. Results from R\&D programs are essential prior to a decision on advanced technologies. Further, since the TWRS program has a fixed terminal point, the need for a continuing major program on alternative techn ologies is no longer needed once the program is defined and accepted.

\section{RESTORE PUBLIC CONFIDENCE IN DOE'S MANAGEMENT OF WASTE}

It is clear that openness, a well defined path through the uncertainties and commitments, and progress toward an early completion of the TWRS program contribute to improved confidence in DOE's programs. The attainment of the three objectives above should be helpful in meeting this objective.

\section{APPROACH}

ESTABLISH A FRAMEWORK FOR EXAMINING SYSTEM ALTERNATIVES TO ASSIST IN DEVELOPMENT OF A STRONG MANAGEMENT PLAN FOR COMPLETING THE TWRS MISSION

The use of the alternatives in deciding on the course to pursue is broader than dependence on the current criteria and decision model; both of which have limitations. There is also a need for 
more detailed understanding of operating restrictions and flexibility as well as efforts to remove serious uncertainties. Further there are issues at the boundaries of the TWRS that, if allowed to be cause for delay, could influence decisions and adversely reflect on public confidence.

\section{IDENTIFY THE ISSUES THAT INFLUENCE THE DECISION PROCESS}

The issues that need to be addressed span the entire integrated system from interim storage in SSTs and DSTs to shipment offsite of either HLW or both LLW and HLW. These are issues involving technology, planning at the EM level, State Governments, other DOE organizations and sites, Government Agencies, and parties to the Tri-Party Agreement.

SELECT A REASONABLE SET OF ALTERNATIVES THAT COVER THE RANGE OF TECHNICAL, OPERATIONAL AND MANAGEMENT ISSUES FOR EVALUATION

The alternatives need to incorporate the judgments of the various groups that have responsibilities impacted by the decisions. These alternatives must open up the current programmatic decisions to assure that there are strong supporting data for continuing the current programs.

RECOGNIZE THAT THERE WILL CONTINUUE TO BE FOLLOW-ON WORK (EVALUATIONS, RESPONSES TO QUESTIONS AND STUDIES OF IMPACTS FROM INTERFACE DECISIONS) FOR A CONSIDERABLE PERIOD UNTIL ALL THE SIGNIFICANT DECISIONS ARE MADE ON COMPLETING THE TWRS MISSION

The acceptance criteria for residual waste quantities left in the tanks for transfer to Closure and in the LLW are examples. There is a need to study in more depth the near and long term budgetary and operating impacts of a system with and without the current sized HWVP, IPM, etc. There are many other examples that could be cited and many more unanticipated ones should be expected in a program of this magnitude, complexity, public visibility, time duration, level of funding, and where responsibilities of organizations outside the DOE are impacted by the DOE program. 


\section{EVALUATION STRATEGY - ALTERNATIVES}

Both early resolution of the tank safety issues and the assurance that the TWRS segment of site closure within the integrated system will be completed on schedule are primary objectives for consideration in a management plan. This must be done without adversely affecting the present program. This requires an examination of the TWRS's current facility planning schedules, the coverage of issues by the alternatives, the status of technology maturity, and the consideration of performance risks of all functions in the integrated system.

From briefings given to the Board, the management plan must consider the issues raised by organizations having responsibilities associated with elements of the site closure process. The participation of these organizations in the selection of TWRS integrated alternatives and the criteria has provided this input. The content of the criteria list is of value even though the yardsticks and data base for measurement are not completely adequate for decisions at this time.

The alternatives do provide guidance for the initial major steps in the implementation of the TWRS program. An evaluation of the alternatives shows that the technology selections are key to setting the pace for completing the TWRS program.

An examination of the ranking using the Board's criteria shows the Board did not give any of the advanced technologies the maximum score in operability and technology maturity. To have high confidence in accelerating the TWRS program a significant development and demonstration program with target schedules is required as part of a management plan.

In addition, the Board included "near-term costs (early budget years)" in life cycle cost as a yardstick. The "near-term costs" coupled with the in-depth evaluation of current program facility planning for the near-term, as suggested in this report, is another essential part of the management plan.

The management plan must cover both the near-term and long-term issues identified in the study of alternatives and specified in the criteria. To initiate discussions on the timing and relationship of the elements of a plan that would meet its objectives, the Board used an overview program schedule that integrated the following: (1) a 
general understanding of the current near-term program schedule, (2) two alternatives with competing technologies that are representative of the chosen set, and (3) the schedules and the decision date on selection of advanced technologies for TWRS. This assures that changes in any one of the above three parts must consider the impacts or benefits on the other two.

The schedule for technology demonstration is consistent with the NEPA process for TWRS and provides time to resolve uncertainties without impeding progress on the TWRS program.

The following is a summary of the program overview presentation.

\section{PROGRAM OVERVIEW}

To better understand program schedule implications, the Board has combined the current Hanford Waste Vitrification Plant (HWVP) schedule and two Waste Remediation Alternative schedules on one Program Overview Schedule (Figure 1). This schedule covers the full range of program start and end dates for all alternatives under consideration so that they can be readily compared. An actual alternative schedule would consist of a subset of this information as illustrated by Figures 2, 3 and 4. Figure 2 shows how deployment of an Advanced Separations alternative (1.2:1.4) would impact the program duration. This of course assumes the development program indicates a high probability of success by the alternative selection decision date in 1998. Figure 3 shows how the High Capacity Melter Alternative (1.2.1.2) which produces both low-level and high-level waste as glass would impact the program duration. Similarily, the development program would need to show a high probability of success for this alternative by the decision date in 1998 . Figure 4 shows how the High Capacity Melter alternative which produces a mixed low-level/high-level waste as glass would impact the program duration.

Starting at the top of Figure 1, it is shown that the program duration would extend to 2044 even if the HWVP capacity was increased approximately three fold to 10 tons per day $(\sim 3 \mathrm{X})$ to accommodate both SST's and DST's. Without this capacity increase, the program would extend into the following century. A three fold increase in melter capacity would need to be supported with development and pilot work and major HWVP design changes to accommodate the larger melter throughput. The supporting sludge washing, cesium 
removal and grout operations are also shown on Figure 1 extending to 2044. The Board has concluded that cesium removal should be included in the program either as part of an Initial Pretreatment Module or as part of some other facility. A program to advance the 2044 date was explored next. The data for the completion dates were supplied by WHC and asssumed successful development, and quality design and operation.

\section{TWRS PROGRAM ACCELERATION - ADVANCED SEPARATIONS}

Two alternatives are shown to reduce the program duration to a shorter time frame with the program ending in 2019 or 2027. More than one alternative was selected to ensure promising technology was not overlooked and to manage risk with each alternative serving as a backup to the other. The development schedules are those considered realistic by the Board if given the necessary priority to permit a narrowing of the program to one principal alternative in 1998. If the Advanced Separaiinns alternative is shown to be feasible and practical by 1998 and if found to be the preferred alternative, it could be piloted in a "Hot" Pilot Plant and the plant designed and constructed on a schedule leading to plant operation in 2020 and Program completion in 2027 (Figure 2). The high-level waste fraction could be converted to glass in the HWVP or in a melter integral with the new Separations Plant if the HWVP is not available. The low-level waste fraction would be processed thiough a grout facility.

TWRS PROGRAM ACCELERATION - HIGH CAPACITY MELTER (LLW \& HLW)

If in 1998 the High Capacity Melter alternative is shown to be feasible and if found to be the preferred alternative, it could commence operation in 2009 with program completion in 2019 (Figure 3). This schedule assumes the HWVP operates until 2009. If all of the waste is processed through the high capacity melter because the HWVP is not available, the program would conclude 3 years later in 2022 (Figure 3 ). The Board sees no reason to combine the high-level waste and the low-level waste if sludge washing capability is provided. It appears practical to campaign the high-level waste through the high capacity melter following completion of low-level waste 
processing so that the high-level waste volumes are not increased.

TWRS PROGRAM ACCELERATION - HIGH CAPACITY MELTER (NO WASTE SEPARATION)

If neither the HWVP or Sludge Washing is provided, the program would conclude in 2022 (Figure 4) with all waste incorporated in a mixed (high-level and low-level) glass product form.

\section{OVERVIEW}

Several programmatic conclusions are apparent from a review of Figures 1 through 4. First, the current capacity of the HWVP is too low to make much of a program contribution from the standpoint of program duration. It would take over 100 years to convert the highlevel waste to glass at its design capacity. Increasing the capacity to 10 tons per day $(\sim 3 \mathrm{X})$ would reduce the program to 44 years. Retaining the HWVP but at this higher capacity would provide substantial risk reduction. Selected tanks could be processed early for operating flexibility and tanks that are considered potentially hazardous to the environment could be removed from service The solutions to problems in operating a production scale glass plant and producing a glass waste form within acceptable parameters would be convincingly demonstrated well ahead of startup of a larger plant. Similarly a skilled and trained operating work force would be available to startup the large plant. An operating HWVP would also add credibility and confidence to the overall DOE program.

It is also apparent that significant reduction in the program duration requires deploying an alternative which incorporates high waste processing capacity. Two broad alternatives are being studied. One is the Advanced Separations alternative which is commonly know as Truex or Clean depending upon the breadth of the processes selected and the other is identified as the High Capacity Melter alternative. The Board has estimated development program schedules which include "Hot" pilot demonstrations for these two broad alternatives. This would be narrowed to one alternative in 1998. It is the Board's judgment that the development schedule for a high capacity melter would be shorter than the development schedule for Advanced Separations. It is also believed that a "Hot" demonstration with a melter of about 20 ton per day capacity and "Hot" piloting of the off- 
gas system would be adequate to support construction of the plant scale equipment. Successful operation of the plant melter at design capacity should be demonstrated "Cold" before plant installation.

It should also be apparent from Figure 1 that the program completion date is established by the development program schedule. Delays in start of the development effort delays the program end date one year for each year of delay. Start of a well focused melter development program in 1993 would also complement the HWVP expansion to 10 tons per day on a timely basis.

The size and scope of DOE's TWRS program requires a well focused and centralized planning effort. The development effort should be properly and adequately staffed, and the staff should be cognizant of technology developed by others. The development effort and the design effort should be managed by the organization responsible for eventual plant operations. In the view of the Board, centralized organizational accountability is necessary if the program is to be successful. The process engineers and key members of the operating staff should become involved early in the development and design efforts to ensure commitment and accountability to the program objectives. A review of causes for failures and successes in industry and government programs (lessons learned) would complement their effort. The development activities must support the design effort on a firm schedule with centralized management of both. It should not be assumed that a free standing development effort can be made to complement a dynamic program. There are many examples of failure in private industry and Government programs where this fundamental requirement was unrecognized or relegated to secondary considerations.

\section{UNRESOLVED PROGRAM ELEMENTS}

Some program elements that the Board feels are either not sufficiently developed or have not been addressed are discussed below. These program elements are included either because of WHC requests, past experience of the Board members, presentations to the Board, or were included in reports on the TWRS issued by other groups. However, the Board feels that a management plan such as the technology development and demonstration program need not be delayed awaiting resolution of the unresolved program elements. 


\section{DECISION ANALYSIS MODEL}

The Decision Analysis Model has been reviewed to assess its usefulness in differentiation among the alternative TWRS strategies. This technique is widely used in private industry where choices must be made for complex systems where parallel choices and series choices have varying probabilities of success and where the best overall choices only become apparent through application of decision analysis methodology. Of course, the success of decision analysis varies directly with the validity of the model and the adequacy of the data base.

In this application the "Performance Measures are the yardsticks by which the alternative TWRS strategies are evaluated". Yet, the performance measures used in the model are different from those being used by the Leadership Council and other groups in their evaluations. These differences raise concerns about the model's usefulness.

Even if we were to accept the Decision Analysis model performance measures as applicable there would be some concerns. Specifically, the model's performance measures include:

- Quantity of high-level waste generated

- Quantity of low-level waste generated

- Peak quantity of new double-shelled tanks

- Quantity of secondary waste generated

- Quantity of reusable or releasable materials generated

- TWRS Program Cost

Also included are seven other performance measures. The first five measures cited above are all cost contributors so that adding the TWRS Program Cost as a measure overly emphasizes cost unless the decision maker intends to emphasize costs in this manner. If so it is not apparent in the other evaluation exercises.

The performance measures of Operability and Technology Maturity, considered most important by this Board, are not included in the model.

The costs that are included in the model are of unequal quality. The model tries to compensate for this by widening the probability bands for low quality cost estimates. Since some of the costs are not 
supported by any engineering data, this effort is totally subjective at best with no assurance that the probability bands are wide enough to actually achieve their iniended purpose.

Finally a proprietary software model called SUPERTREE is employed to calculate the effects of technical uncertainties on a specific performance measure. Whether SUPERTREE is applicable to the TWRS analysis could not be ascertained.

Since the Decision Analysis Model doesn't use the performance measures being used by the evaluators to differentiate between alternatives and for the other reasons cited, the model's use should be limited. As currently configured it should not be expected to provide reliable results.

\section{COMPACT PROCESSING UNIT CONCEPT}

The Compact Processing Unit Concept (CPU) is one of several design concepts that could be evaluated for use in the TWRS program. The concept is to provide movable individual process modules that, in connection with a central service facility, can perform a specific function on given waste inventories. Process modules would be added as necessary to perform all of the required operations in connection with assigned waste tanks and then moved to the next location. Failed modules would be transported to a central maintenance facilit' $j$ for major repairs.

The CPU concept can be placed in perspective as a design concept by comparing design criteria for a conventional centrally located plant with design criteria for a CPU complex. These design criteria shown in Table 6 are not intended to be all inclusive but permits a comparisin based on some of the major design considerations.

As illustrated by Table 6, most of the design criteria for either concept are common. But, there are some significant differences. Portability is required by the CPU's. The designer will have to provide design features to make this possible and these features are an important cost consideration. Closely allied with portability is the requirement for containment during transport. A transportable confinement system to be moved with the CPU to maintain the CPU at negative pressure might be an alternative but it becomes a cost item as well. For the supply of liquid feed the conventional plant 
relies on a piping transfer system while the CPU's are moved from site to site.

The impact of this mode of operation on safety and the environment is judged to be severe. The suggestion that it is more economic to move the plant to the waste than to move the waste to the plant seems unlikely. In the case of Advanced Separations alternatives several modules would be employed in series. Surge capacity between modules would be required to make the system operable. It is not apparent how this capacity could be provided. Failure of a module would shut the system down for the period of time required to transport the module to the repair facility, perform the repairs and return the module to the field. Confirmation that the repair was successful would need to be made before the module is returned to service. Unsuccessful repairs would require return of the module to the central maintenance facility for additional work. The connections between the modules could potentially leak and would require secondary confinement or containment barriers depending on the status of the ventilation system. For series operations of three or more modules the operating efficiency would be expected to be less than 50 percent. The number of control rooms required to monitor and control the processes affects the size of the operating staffs and thus operating costs. Each control location would require one to two operators.

There are other design considerations that bear on the merits of the CPU concept. Frequently the size of the envelope for enclosing the equipment is not set by the size of the equipment but rather by hydraulics or wall surface area required for service line penetrations with their remote connectors. Hydraulic considerations may establish the height of the envelope because gravity flow is preferred over pressurized lines and pumps for safety and operating efficiency reasons. Hydraulics are also relied upon to avoid backup or siphoning of process solutions into occupied areas. Further, all of these pipe penetrations must be protected by liquid seals to avoid contaminated air flow into occupied areas.

Based on a comparison of criteria and other design and operating considerations it is apparent that the CPU's will not be cost competitive with a well designed conventional plant. This conclusion is supported by experience at the Savannah River Plant where variations of the CPU were costed and then abandoned. 


\section{MELTER FOR HIGH THROUGHPUTS}

The current HWVP melter was originally designed for processing only the wastes currently stored in the double shell tanks and the fresh waste from the operation of the Purex separation facility. The design throughput of this melter is 2.74 tons per day at $100 \%$ attainment. This is not sufficient to support a program aimed at processing wastes from both the single and double shell tanks in a reasonable period of time. The following alternatives are being considered.

- Installation of a different type of melter in the HWVP or multiple current melters that would increase the vitrification capacity to a nominal 10 tons per day.

- Development of a different type of melter with much higher throughputs (the VORTEX type combustion heated melter and a stirred melter are under consideration).

The Board believes that any significant increase (probably in the range of 50 to $100 \%$ increase) in melter capacity necessitates a comprehensive research and development program. In the development of any new melter, it is important to concentrate on a number factors pertaining to design and operation. This is especially important since this melter will be used in radioactive service.

The Board believes that the issue of feeding a dry material rather than a slurry to the melter should be revisited; this is consistent with the original design of the vitrification system for the DWPF and the operation of the French melter. The dry feed approach to the DWPF melter was dropped early in the program when experimental results showed that the slurry fed melter could process the required quantity of radioactive waste and the elimination of the calciner reduced the height of the DWPF and resulted in considerable cost savings. Normal commercial operation of a joule heated melter utilizes a dry feed. Feeding the waste as a slurry requires a large increase in the amount of energy which must be generated in the melter or in the plenum by the lid heaters to evaporate the water. Furthermore, the low temperature of the glass near the surface (tempered by the boiling temperature of the water) creates a barrier to the interaction of the waste solids (cold cap) and the molten glass. This is probably the main cause for the significantly lower throughput of slurry-fed melters when compared with diry-fed 
industrial melters. Considerably higher throughputs are achievable if extensive dehydration of the feed is provided.

The Board members feel that the alternatives utilizing a higher capacity melter offer a much higher probability of success as shown in its rankings. However, the Board feels that the development of a higher capacity melter presents uncertainties that can only be answered by a comprehensive research and development program. The Board realizes that on-going work in industry and other DOE sites must be closely monitored to both expedite the development process and ensure the chance of success. The success of a high capacity melter program will necessitate both a strong team and priority efforts at Hanford. This effort must cover the following:

- Feed Preparation and Delivery System

- Melter System

- Off-Gas System

- Glass Quality and Monitoring Facility

\section{WASTE PROCESSING LOGISTICS}

There is a strong interest in completing the processing of waste for tank farm closure as soon as practicable. Alternatives with the highest processing rates complete processing in about 13 years. This raises questions as to whether the required waste handling logistics can support a 13 year program.

The single shell tanks will produce 120 million gallons of $5 \mathrm{M}$ sodium solution when they are sluiced. The double shell tanks will produce 30 million gallons of $5 \mathrm{M}$ sodium solution for a total of 150 million gallons. After evaporation the sodium concentration could be as high as 10 to 12 molar. Assuming $10 \mathrm{M}$ sodium, there will be 75 million gallons of melter feed; this assumes all of the sodium is fed to the glass melter. This is equal to 5.8 million gallons per year for a 13 year program or an average of 26,000 gallons per day assuming $60 \%$ operating efficiency. This equates to 18 gallons per minute for a single melter or 9 gallons per minute per melter for a plant with two melters. These quantities and rates are well within the state of the art with respect to pumping radioactive solutions in the tank farms and in reprocessing plants. However, this volume of waste probably exceeds what has been handled in the waste tank farms in the past especially if blending and a large amount of sampling is required. 
The 5.8 million gallons of waste per year would produce 139,000 cubic meters of glass with a specific gravity of 2.65 or 405,000 tons of glass which equates to 31,000 tons per year, 140 tons per day assuming $60 \%$ efficiency or 70 tons per day per melter. A development program that demonstrates a 20 ton per day melter "Hot" and a 70 ton per day melter "Cold" would complement these required rates.

From the Board's perspective a 13 year campaign appears practical provided the melter development program is successful and provided the tank farm infrastructure of pipe lines and sluicing and pumping equipment are designed and built on a schedule that supports the balance of the program.

While a 13 year program appears practical, it may not represent an optimum balance between cost, development program objectives and the incentives for early tank farm closure. For example, extending the program to 26 years would halve the flow rates described above, this would reduce capital cost by either requiring that one melter be installed or reducing the capacity of each of two melters to about 33 tons per day. The reduced melter capacity probably would be easier to attain than a larger melter. This comparison suggests a study should be made to arrive at the optimum program duration to balance these and other considerations and to set development targets.

\section{ORGANIC DESTRUCTION}

Some of the waste stored in tanks contains organic and organometallic compounds which are slowly decomposing. The decomposition products include hydrogen gas which accumulates in the tank vapor space and represents a potential safety concern. Airhydrogen gas mixtures become explosive at relatively low concentrations, on the order of 4 percent. Identified treatment methods include digestion at temperatures on the order of $90{ }^{\circ} \mathrm{C}$, ozone or hydrogen peroxide oxidation, steam reforming, supercritical water oxidation, incineration/calcination and high-energy processes such as plasma, electron beam and corona discharge. If grout is the selected waste form, it will be necessary to remove or destroy the organic compounds before the wastes are incorporated into grout. If processing of low-level waste includes high temperature processes such as calcination or vitrification, complete destruction of the organic compounds would be expected. This is an important 
consideration in the selection of a treatment process for Hanford low level waste. However, it is important that process demonstrations be performed on actual waste samples. This screening and demonstration work should be throughly explored before a commitment is made to build plant facilities.

\section{SHIPPING A HIGH LEVEL CONCENTRATE TO SAVANNAH RIVER}

The alternative of shipping an intermediate high-level waste form, after pretreatment in advanced processes, to Savannah River for vitrification did not have sufficient definition for a thorough assessment. There are issues of the shipping waste form and characteristics, inter-state shipping requirements, NRC requirements, PEIS coverage, and Savannah River capacity, capability, NEPA, unrestricted land use, costs, acceptance of radioactive waste generated out of state, etc. The transportation issues and environmental risks alone raise serious questions about this alternative. It is questionable whether this alternative is a viable one to include in the Ranking.

\section{TWRS INTEREACES}

The many interfaces and interactions with the Closure system have not been completely defined. Since the final scope of the TWRS-EIS is not finalized there is an uncertainty in the comparability of the TWRS Study and EIS boundaries. as well as in firmness of the Closure interfaces. Figure 5 is a WHC graphical presentation of the interface issues.

\section{ACCEPTANCE CRITERIA}

There are various materials and equipment that cross the boundaries of the TWRS as shown by the WHC chart in Figure 6. The acceptance criteria on these transfers could influence the effort within the TWRS. This also applies to transfers of any wastes into TWRS from clean-up in the closure system. Comments on LLW and HLW are provided below because they are used in the discussion of the alternatives.

The classification of the low-level waste is an issue. Until LLW has been characterized, it is not known whether it meets the EPA criteria for land disposal. This applies to grout or glass with high sodium content. 
There are two acceptance criteria that are potential issues with HLW. The first is the residual HLW content in tanks turned over to closure. The second is the glass characteristics to be sent to the repository. The different compositions of the tank waste and the processing of high sodium waste into borosilicate glass will probably require extensive testing under NRC waste characterization procedures before the waste forms would be accepted. This could influence the alternative in which all waste is shipped as a glass to the repository.

\section{HIGH-LEVEL WASTE REPOSITORY}

The repository costs for all alternatives, the acceptance of large quantities of glass produced in the alternative for immobilizing all tank waste as a mixed waste for off-site disposal and the use of the second repository were issues raised.

\section{CONTACT MAINTAINED MELTER FOR LOW LEVEL WASTE}

If an Alternative to produce a glass waste form from the low-level waste is selected, a study should be made to determine if a direct maintenance melter with supporting equipment can be utilized. Of course, the feasibility of direct maintenance with its inherent cost advantage will be determined by the radioactivity level in the waste. If the production of a Class A low-level waste is required as it was at West Valley and Savannah River, the radioactivity may be low enough to operate a direct maintenance melter. If a direct maintenance facility is feasible from a radioactivity standpoint, it offers the potential of installation of a melter that does not have to be constructed so that it can be handled remotely. This would allow use of construction methods much more comparable to commercial melters rather than the very costly construction that is necessitated for remote handling.

\section{GROUND WATER RECHARGE RATES}

Grout performance assessments are based on a constant ground water recharge rate of $0.1 \mathrm{~cm}$ per year. However, there are at least two sets of data taken in 1992, provided to the Board, that suggest the recharge rates in some 200 area locations approaches zero. This ground water recharge rate of $0.1 \mathrm{~cm}$ per year should be revisited with the objective of refining the value and establishing a valid technical basis for grout or other waste performance assessments in 
Appendix B-3

the 200 areas. The $0.1 \mathrm{~cm}$ per year criterion may disqualify concepts which on total balance of criteria may be acceptable choices. 
Appendix B-3

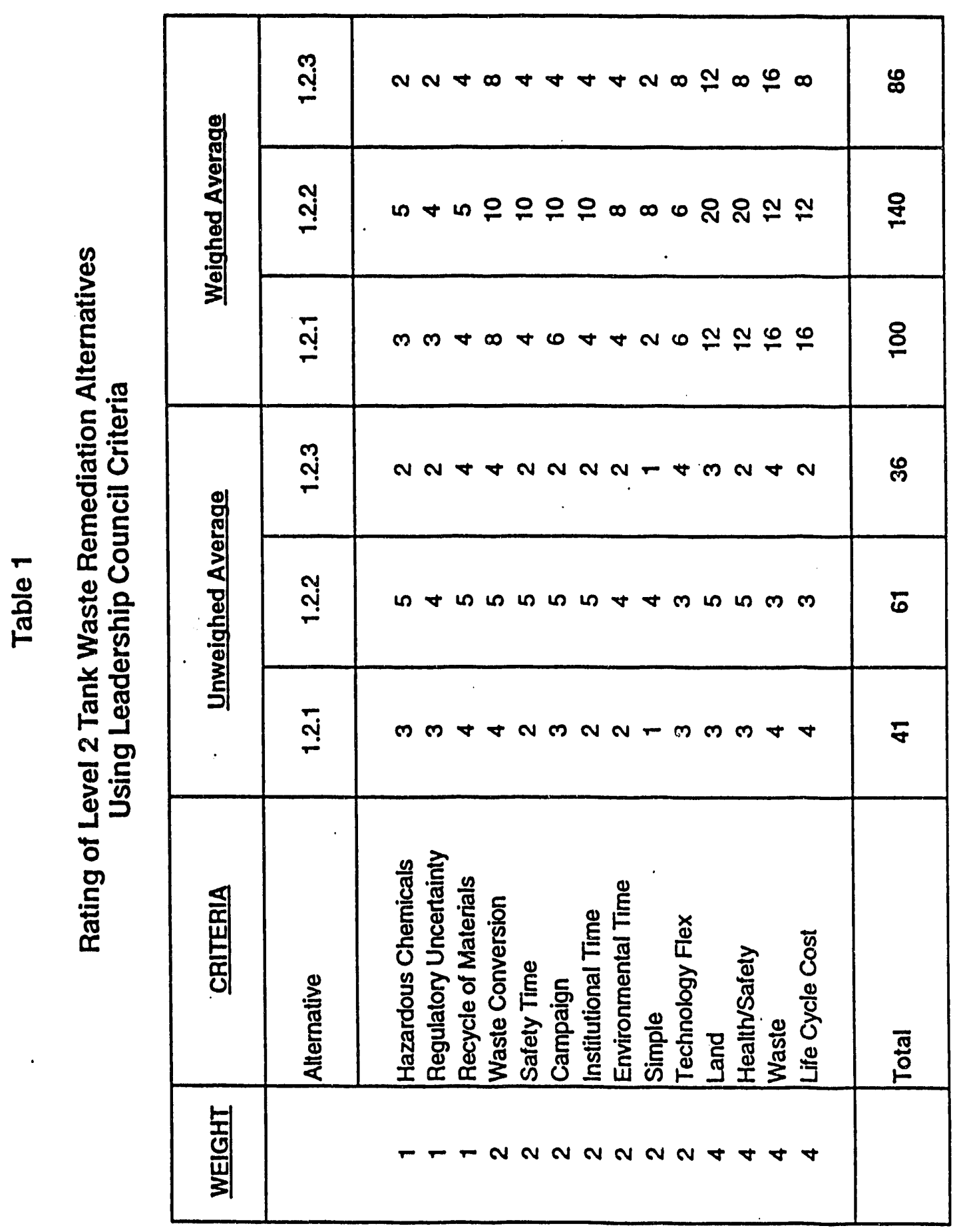


Table. 2

Rating of Level 3 Tank Waste Remediation Alternatives Using Leadership Council Criteria

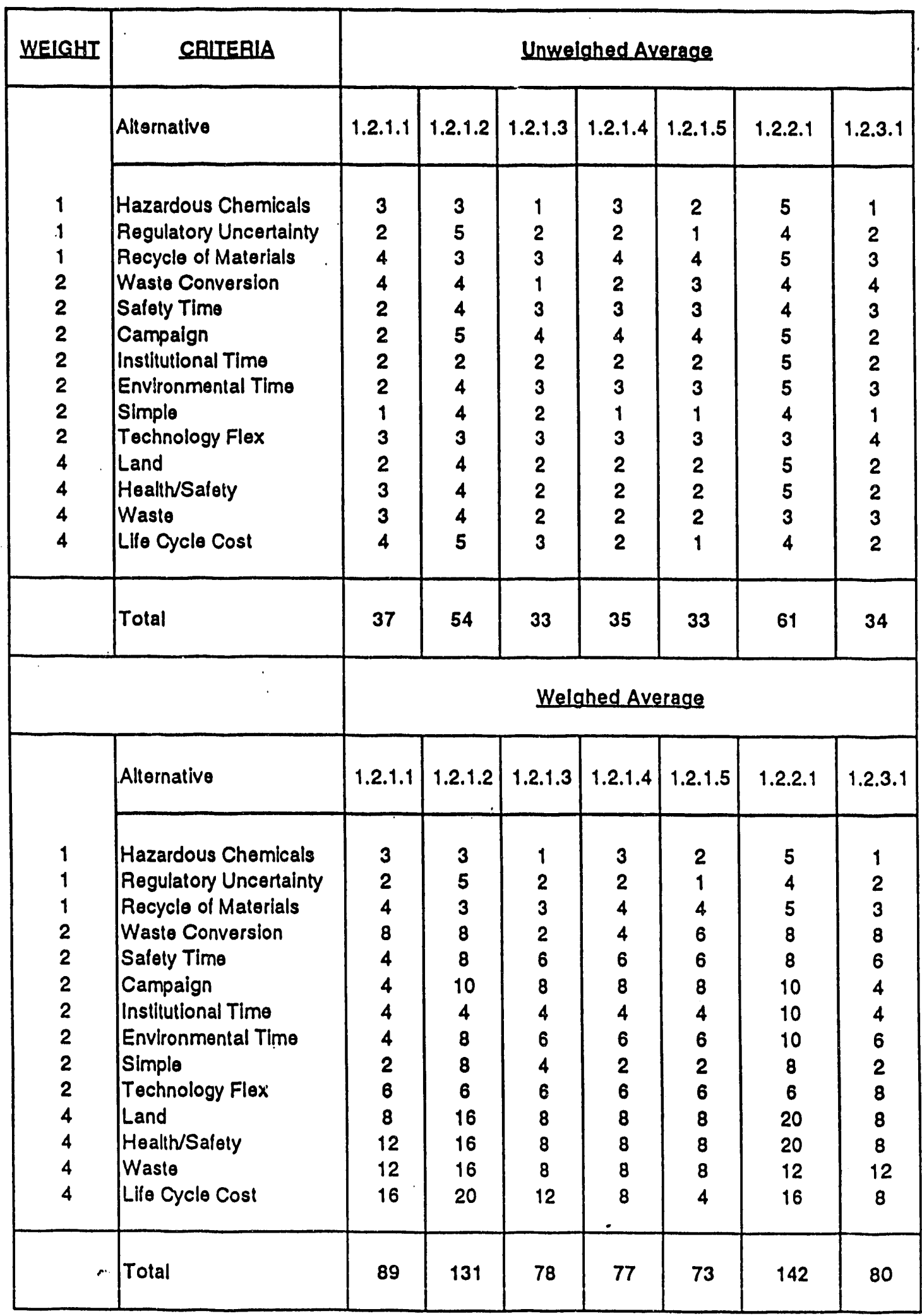


Table 3

\section{SYSTEM ENGINEERING TECHNICAL ADVISORY BOARD'S}

\section{CRITERIA}

WEIGHT CRITERIA

5 OPERABILITY/RELIABILITY

5 TECHNOLOGY MATURITY

3 PROGRAM DURATION (LEADERSHIP COUNCIL CRITERIA 6 )

3 LIFE CYCLE COSTS (LEADERSHIP COUNCIL CRITERIA 14)

2 SAFETY (LEADERSHIP COUNCIL CRITERIA 12)

PUBLIC

WORKER

2 OTHER ENVIRONMENTAL (AVERAGE OF LEADERSHIP COUNCIL CRITERIA 3, 11 \& 13)

1 REGULATORY COMPLIANCE (AVERAGE OF LEADERSHIP COUNCIL CRITERIA $1 \&$ 2) 
Table 4

Rating of Level 3 Tank Waste Remediation Alternatives Using System Engineering Technical Advisory Board Criteria

\begin{tabular}{|c|c|c|c|c|c|c|c|c|}
\hline WEIGHT & CRITERIA & \multicolumn{7}{|c|}{ Unwelghed Average } \\
\hline \multirow{3}{*}{$\begin{array}{l}5 \\
5 \\
3 \\
3 \\
2 \\
2 \\
1\end{array}$} & Alternative & 1.2.1.1 & 1.2.1.2 & 1.2.1.3 & 1.2.1.4 & 1.2.1.5 & 1.2 .2 .1 & 1.2 .3 .1 \\
\hline & $\begin{array}{l}\text { Operability and Reliability } \\
\text { Technical Maturity } \\
\text { Schedule Campaign } \\
\text { Lille Cycle Cost } \\
\text { Öther Environmental } \\
\text { Safely } \\
\text { Regulatory Compliance }\end{array}$ & $\begin{array}{l}1 \\
1 \\
2 \\
4 \\
3 \\
3 \\
3\end{array}$ & $\begin{array}{l}3 \\
3 \\
5 \\
5 \\
4 \\
4 \\
4\end{array}$ & $\begin{array}{l}2 \\
2 \\
4 \\
3 \\
2 \\
2 \\
2\end{array}$ & $\begin{array}{l}1 \\
1 \\
4 \\
2 \\
3 \\
2 \\
3\end{array}$ & $\begin{array}{l}1 \\
1 \\
4 \\
1 \\
2 \\
2 \\
2\end{array}$ & $\begin{array}{l}4 \\
3 \\
5 \\
4 \\
5 \\
5 \\
4\end{array}$ & $\begin{array}{l}1 \\
1 \\
2 \\
2 \\
3 \\
2 \\
2\end{array}$ \\
\hline & Total & 17 & 28 & 17 & 16 & 13 & 30 & 13 \\
\hline & & \multicolumn{7}{|c|}{ Welghed Average } \\
\hline & Alternative & 1.2.1.1 & 1.2.1.2 & 1.2.1.3 & 1.2.1.4 & 1.2.1.5 & 1.2.2.1 & 1.2.3.1 \\
\hline $\begin{array}{l}5 \\
5 \\
3 \\
3 \\
2 \\
2 \\
1\end{array}$ & $\begin{array}{l}\text { Operability and Reliability } \\
\text { Technical Maturity } \\
\text { Schedule Campaign } \\
\text { Lile Cycle Cost } \\
\text { Other Environmental } \\
\text { Salety } \\
\text { Regulatory Compliance }\end{array}$ & $\begin{array}{c}5 \\
5 \\
6 \\
12 \\
6 \\
6 \\
3\end{array}$ & $\begin{array}{l}15 \\
15 \\
15 \\
15 \\
8 \\
8 \\
4\end{array}$ & $\begin{array}{c}10 \\
10 \\
12 \\
9 \\
4 \\
4 \\
2\end{array}$ & $\begin{array}{c}5 \\
5 \\
12 \\
6 \\
6 \\
4 \\
3\end{array}$ & $\begin{array}{c}5 \\
5 \\
12 \\
3 \\
4 \\
4 \\
2\end{array}$ & $\begin{array}{c}20 \\
15 \\
15 \\
12 \\
10 \\
10 \\
4\end{array}$ & $\begin{array}{l}5 \\
5 \\
6 \\
6 \\
6 \\
4 \\
2\end{array}$ \\
\hline & Total & 43 & 80 & 51 & 41 & 35 & 86 & 34 \\
\hline
\end{tabular}


Table 5

\section{TOTAL LIFE CYCLE COST*}

Alternative

$$
\text { Estimated Total Life Cycle Cost (SB) }
$$

Constant Dollars Discounted Dollars

1.2.1.1

1.2.1.2

30.9

15.1

25.4

34.2

13.1

1.2.1.3

1.2 .1 .4

38.5

18.3

1.2 .1 .5

31.6

18.3

1.2 .2 .1

35.6

17.1

14.8

1.2.3.1

37.5

15.0

*Cost Numbers Supplied by Westinghouse Hanford Company 
Table 6

\section{COMPARISON OF DESIGN CRITERIA FOR CONVENTIONAL PLANT AND CPU'S}

\section{Criteria}

Feed Quantities \& Characteristics

Solidified Waste Form

Gaseous Releases

Liquid Releases

Occupational Exposures

Accident Mitigation

Resistance to Tornadoes

Resistance to Earth Quakes

Double Confinement

Double Containment

Portability

Control Rooms

Waste Feed Transport

Maintenance

Weather Protection

Decommissioning

Operating Efficiency

\section{Conventional Plant CPU's}

Same

Same

Same

Same

Same

Same

Same

Same

Same

Not Required

Not Required

Centralized

Pipelines

Within Plant

Conventional

Conventional

$60.70 \%$
Required

Required

Dispersed

Move CPU's

Move CPU's

Special Features

Support Facility

30-50\% 
Appendix B-3

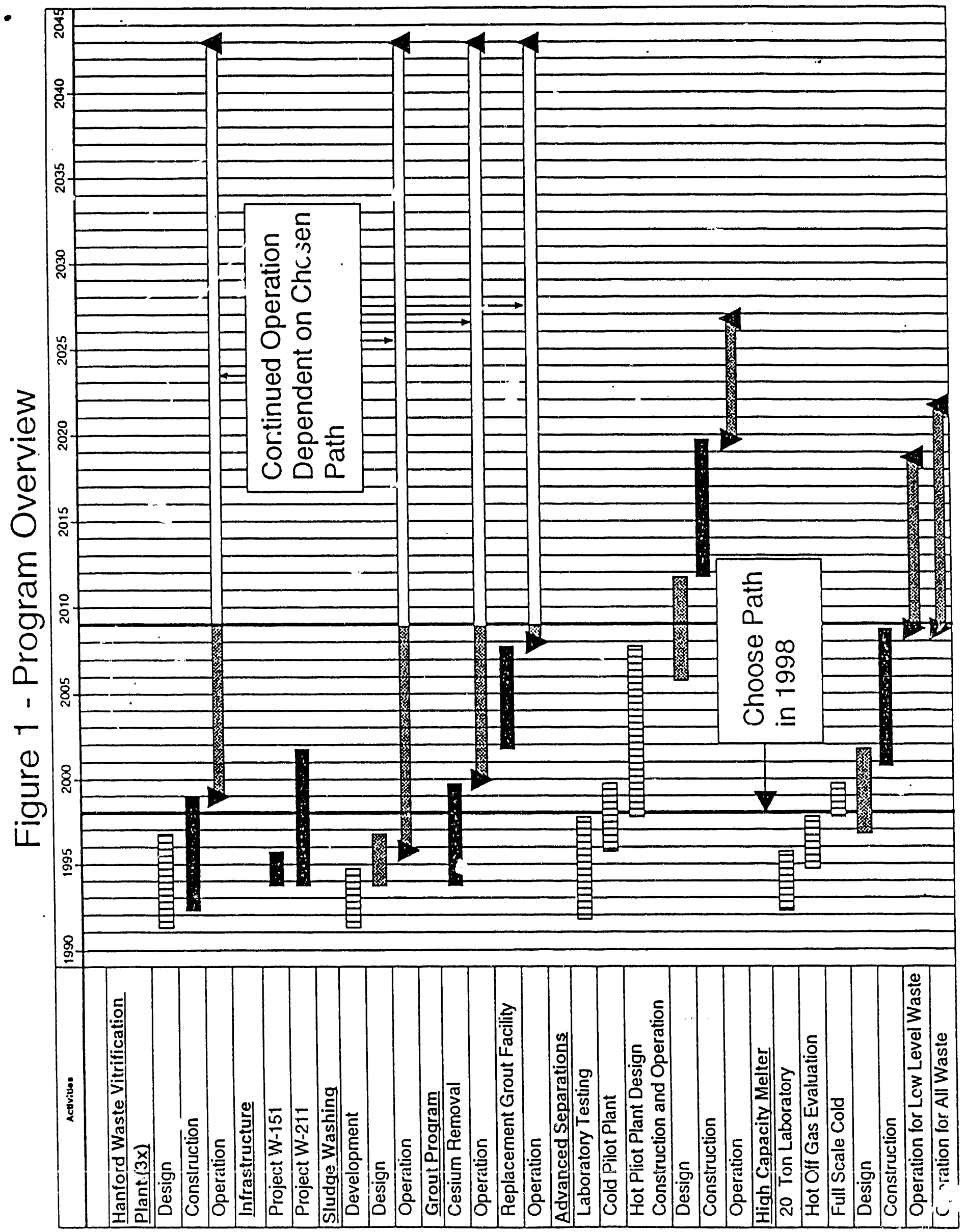

Page 65 
Appendix B-3

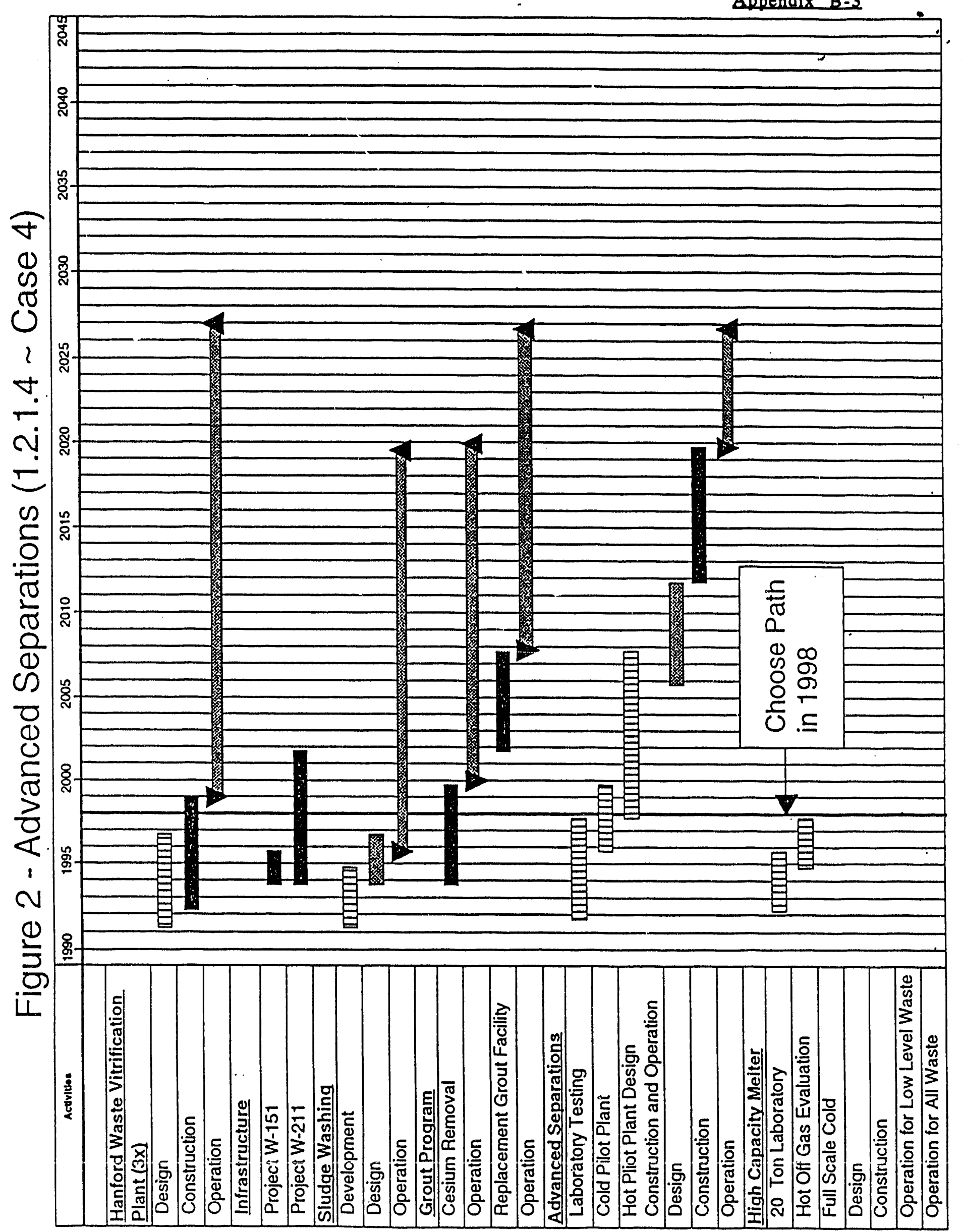

Page 66 
Appendix B-3

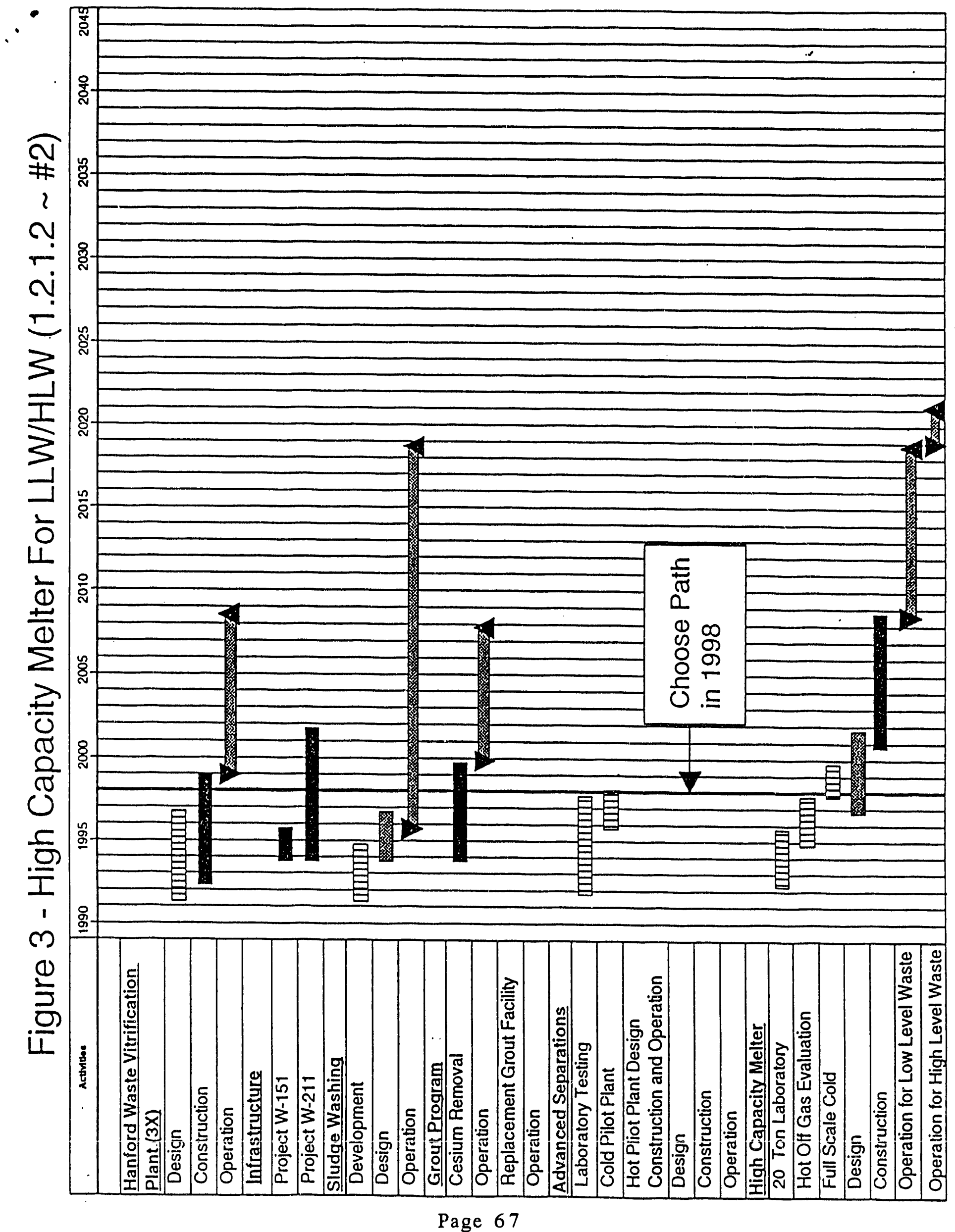




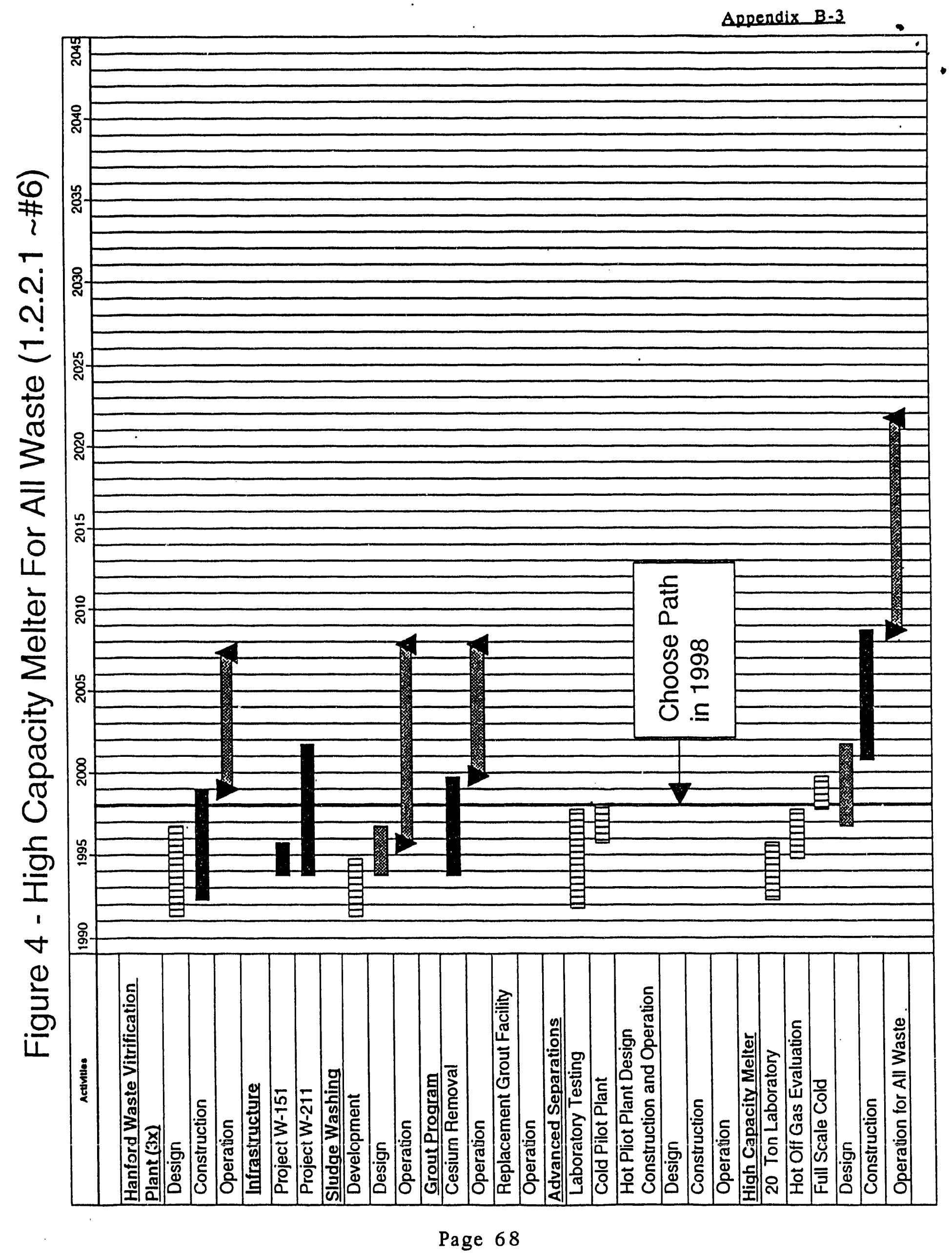


Appendix B-3
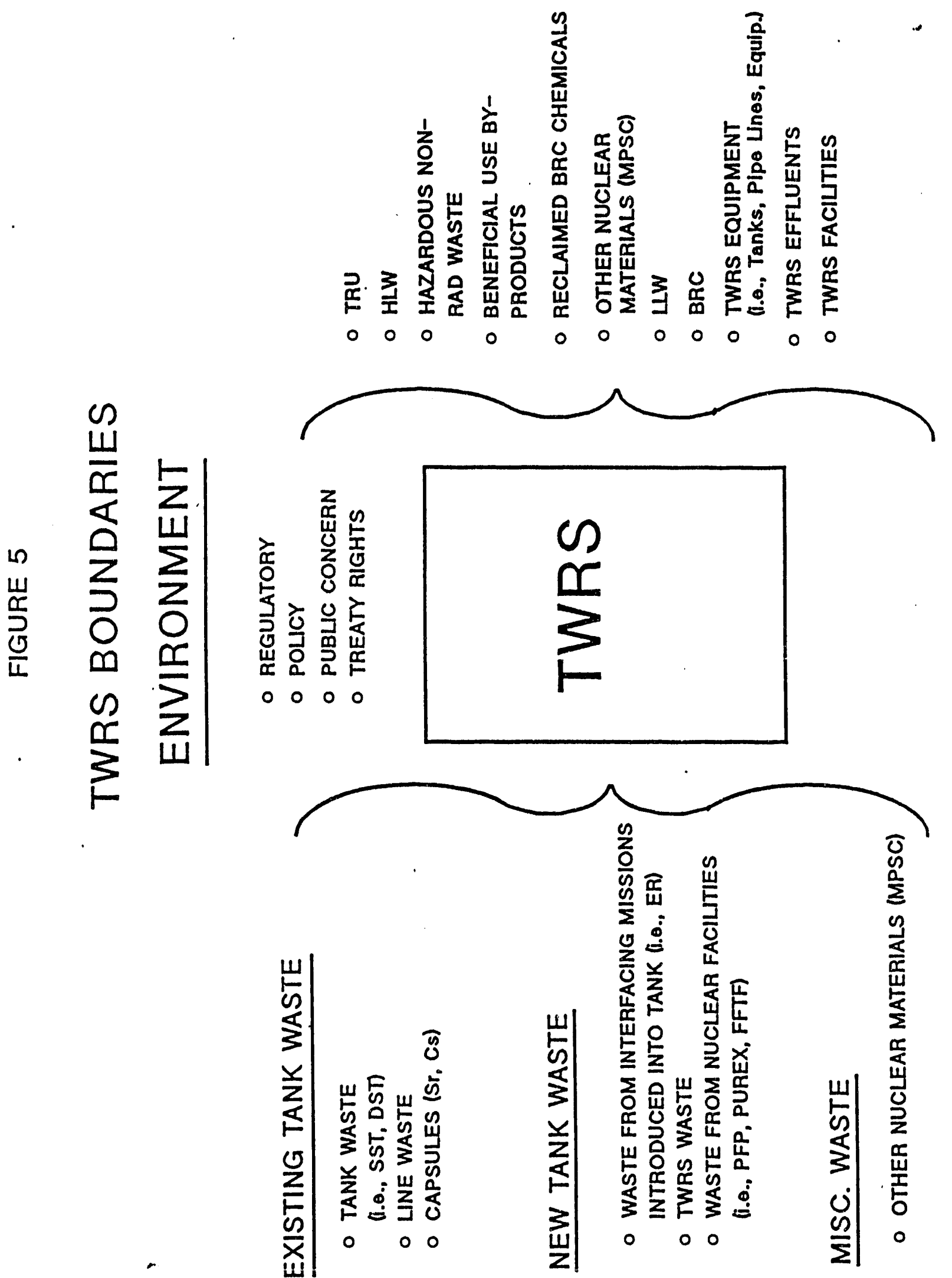

Page 69 
Appendix B-3

影影

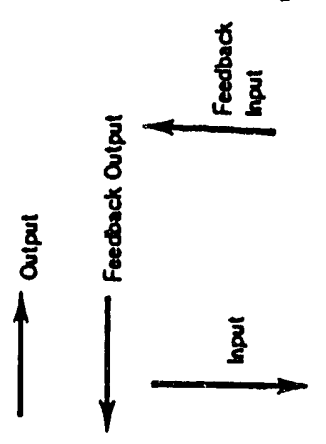

!n!

0

荘

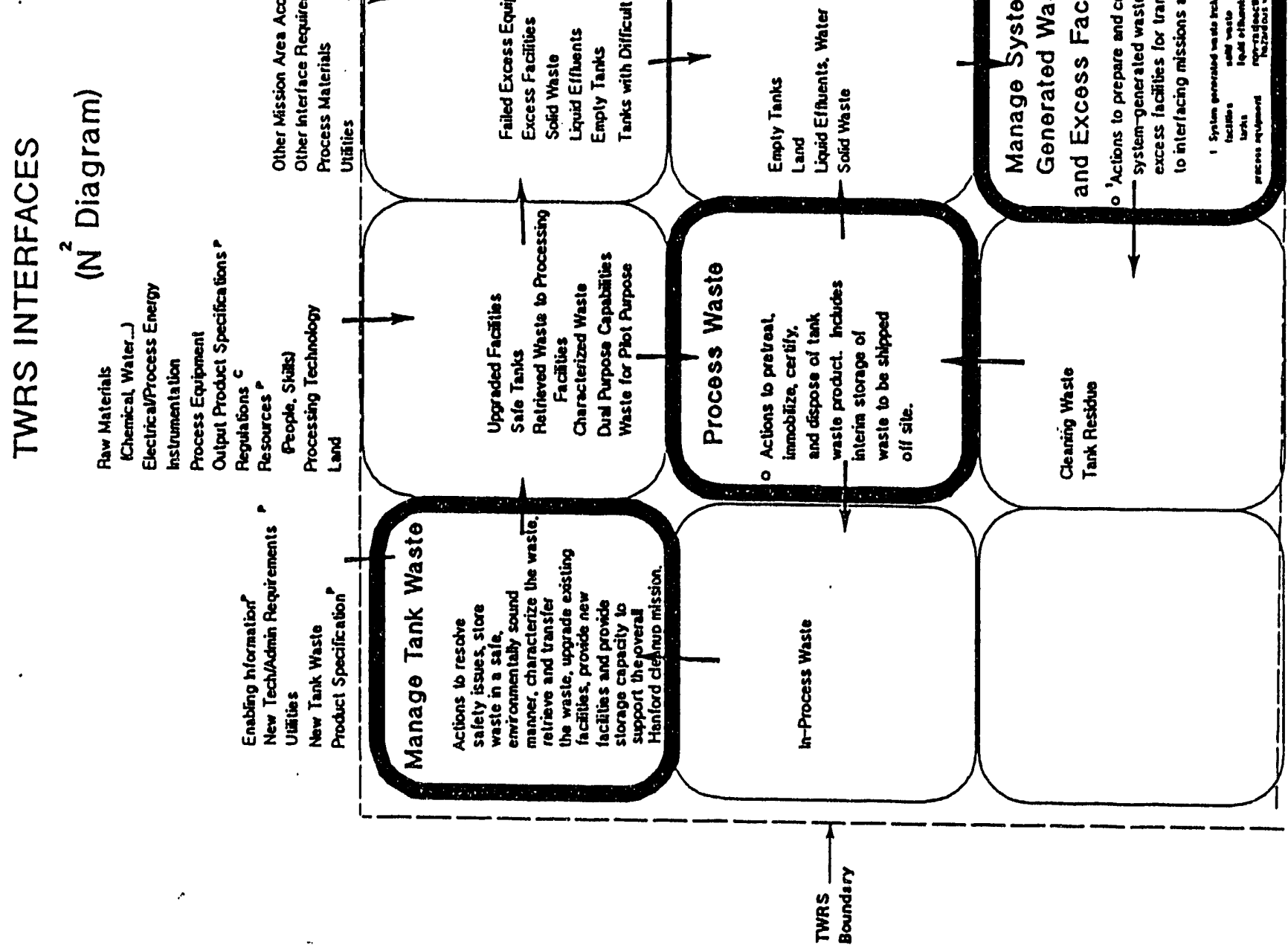



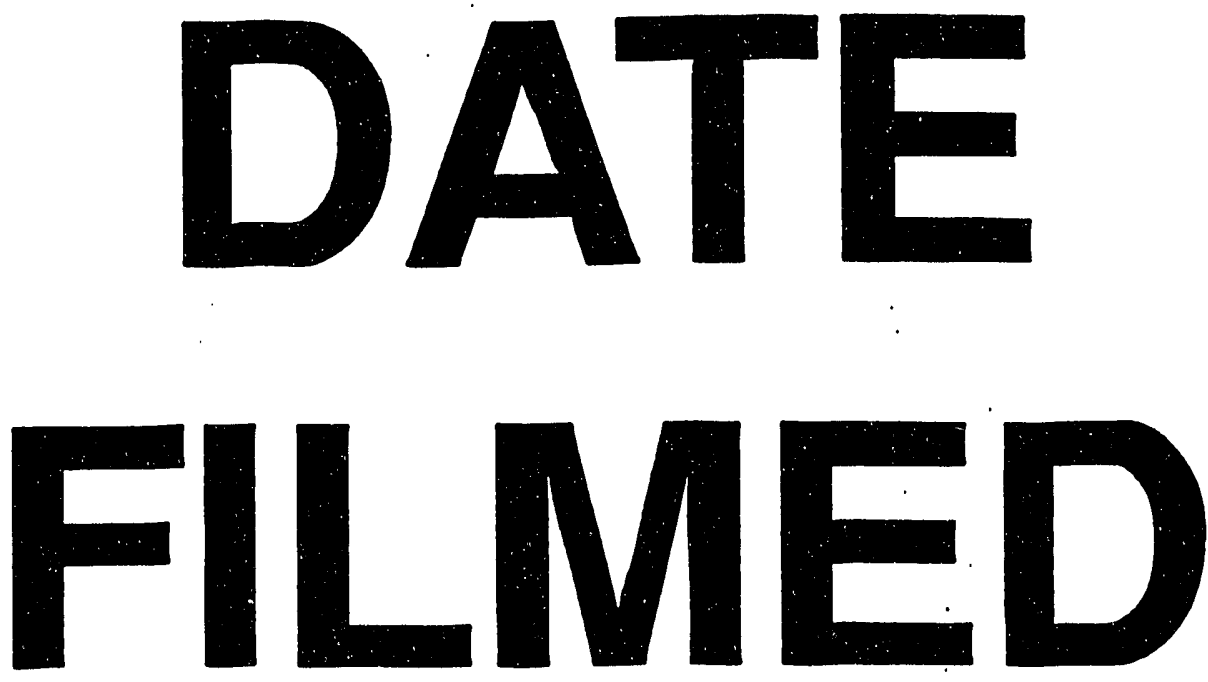

$10 / 7 / 93$
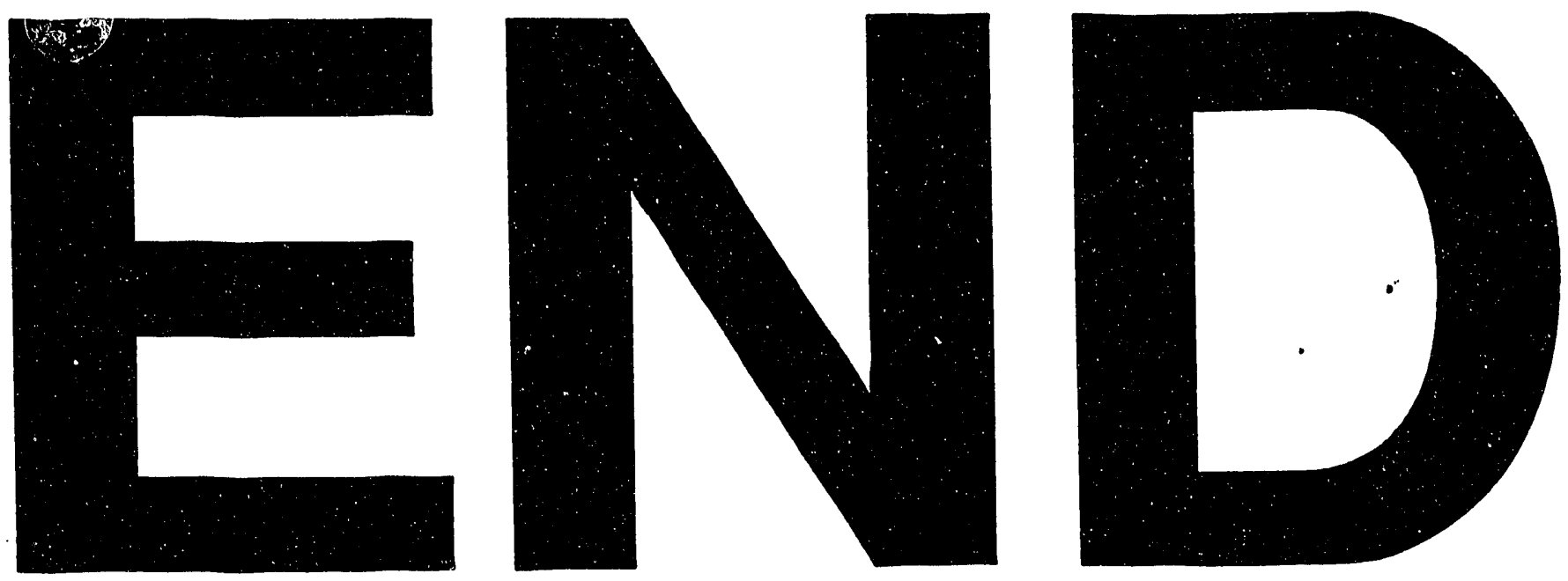
